Canadian Studies in Population 43, no. 1-2 (2016): 78-116.

\title{
Canada's immigration trends and patterns
}

\author{
Barry Edmonston ${ }^{1}$
}

\begin{abstract}
Canada was settled by immigrants, including Aboriginal peoples who arrived thousands of years ago, French and British settlers who first began arriving in the 1600s, and people from many other nations who have migrated in the past four centuries. Now, almost 150 years since the Confederation of Canada in 1867, immigrants numbered 6.8 million and comprised 20 per cent of the total population in 2011. Canada's population has completed the demographic transition from high mortality and fertility to relatively low vital rates, accompanied by continued, fluctuating international migration. Canada's population reflects this fertility and mortality history, as well as the effects of international migration. Immigration has increased in significance in recent decades as one of the key factors influencing population change. This paper examines Canada's trends and patterns in international migration.
\end{abstract}

Keywords: Immigration history, Canada, population change, emigration.

\section{Résumé}

Le Canada fut colonisé par des immigrants, y compris les Autochtones qui arrivèrent il y a des milliers d'années, les colons français et britanniques dès les années 1600 et les peuples de beaucoup d'autres nations qui migrèrent au cours des quatre derniers siècles. De nos jours, presque 150 ans après la fédération canadienne de 1867, le pays accueillit 6,8 millions d'immigrants qui représentèrent 20 pour cent de la population totale en 2011. La population canadienne compléta la transition démographique, allant d'une mortalité et fertilité élevée à des indices vitaux relativement bas, mais toujours accompagnés d'une migration internationale continue et fluctuante. La population canadienne reflète cet historique de fertilité et mortalité ainsi que l'effet de la migration internationale. L'immigration a pris plus d'importance au cours des dernières décennies en tant qu'un des facteurs clés influençant les fluctuations démographiques. Cet article examine les tendances et les pratiques en matière de migration internationale.

Mots-clés : historique de l'immigration, Canada, fluctuations démographiques, émigration.

\section{Introduction}

Canada is a nation primarily composed of immigrants and the descendants of immigrants. The nation has a long and complex immigration history. An understanding of this history is indispensable in order to appreciate the present ethnic background and the contribution of immigration to Canada's population change. Moreover, immigrant origin and ethnic origin remain an important factor in the social, political, and economic lives of many people. The fact that a large and increasing fraction of Canadian residents is foreign-born means that ethnic heterogeneity remains high. The number of

1. Research Professor, Department of Sociology and Population Research Group, University of Victoria, PO Box 3050 STN CSC, Victoria BC V8W 3P5. E-mail: be@uvic.ca. 
foreign-born persons is currently large, and the number of children and grandchildren of foreignborn persons is much larger, and will continue to increase.

This paper provides a survey of Canada's immigration trends and patterns. It is not intended to be an exhaustive review of the state of knowledge of immigration to Canada. Rather, this paper limits attention to an historical overview of demographic trends in international migration since the mid-1800s, a summary of data on the composition and characteristics of the recently arrived and total foreign-born population, a short discussion of two key factors affecting immigrant integration, and the demographic effects of Canada's immigration. The paper ends with a discussion of future prospects for Canadian immigration, including national population projections, public opinion on Canada's immigration, and concluding remarks.

\section{International migration trends}

Since 1851, immigration flows to Canada have averaged around 120,000 arrivals per year, with considerable variation from the peaks during the 1900s, 1910s, and 1950s to the valleys of the 1890s, late 1910s, 1930s, and early 1940s. Figures 1 and 2 trace the history of immigration to Canada since the inception of population censuses for Canada in $1851 .{ }^{2}$ Figure 1 shows annual immigrant arrivals for 1851 to 2014. Figure 2 presents five-year annual averages for immigration, emigration, and net immigration, in order to highlight the main trends that may be obscured in volatile annual data. These figures show the immigration boom that occurred during the period of 1900 to 1914. Immigration from Europe was especially numerous during this period, which was a time of population settlement of the Prairie provinces and rapid urbanization and industrialization throughout Canada. The peak year for admission of immigrants to Canada was 1913, when almost 350,000 immigrants entered and added about 5 per cent to the Canadian population in one year alone. From 1880 to 1930 there was prolonged large-scale immigration from Europe to Canada; during this fifty-year period, immigration exceeded 10 immigrants per 1,000 population, with comparatively much higher rates in the late 1880s and from 1900 to 1914. However, during this period, high levels of emigration, especially of Canadian-born residents, offset immigration levels, with net out-migration for most of the 1870 to 1900 period.

The five-year period of 1909 to 1913 witnessed the largest volume of Canadian immigration, in both absolute and relative terms, with the arrival of 1.3 million immigrants, or more than 250,000 annually. By 1913, more than one-sixth of the Canadian population had arrived in the preceding five years. Limiting attention to the foreign-born population in 1913, about one-half had arrived in Canada in the prior five years.

Immigration levels declined during World War I and increased in the early 1920s. As economic conditions worsened in Europe in the 1920s, migration to Canada increased after 1918, averaging about 100,000 immigrants annually in the early 1920s and almost 150,000 immigrants in the late 1920s. In contrast, few immigrants came during the 1890s, World War I, and the 1930 to 1945 period of the Great Depression and World War II. There were only about 15,000 immigrants arriving per year on average in the 1930s, and the numbers decreased even further during World War II, to a low of 7,500 immigrants in 1942. At the same time, there was substantial emigration from Canada during the 1930s, resulting in net outmigration during the Depression years.

2. Immigration and emigration tables and figures are based on published Statistics Canada data and are discussed in the Appendix. See Edmonston and Michalowski (2003) for a discussion of international migration data and definitions. See Simmons (2010), Boyd (2011), and Beaujot and Raza (2013) for additional descriptions of Canadian immigration trends. 


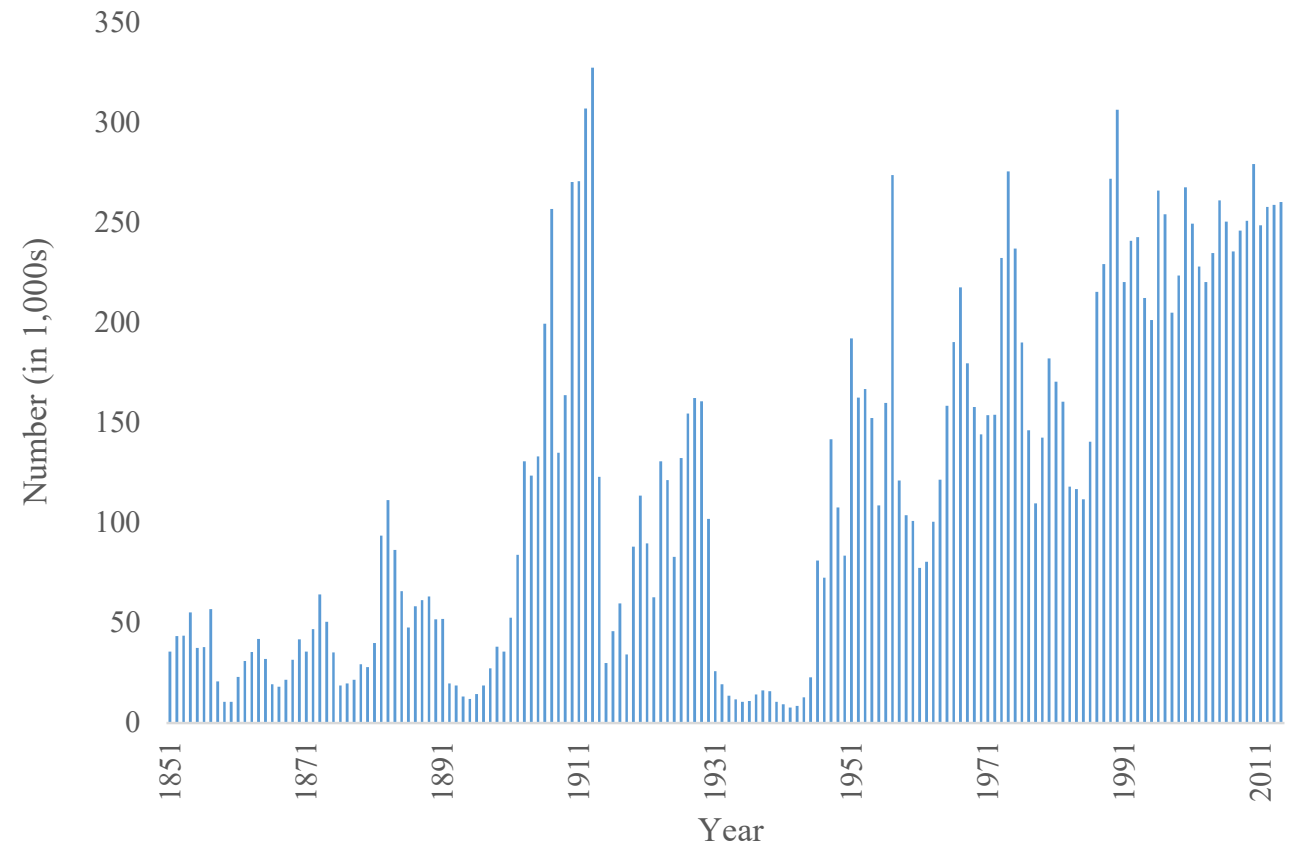

Figure 1. Annual number of immigrant arrivals (in 1,000s) for Canada, 1851-2014. Sources: Citizenship and Immigration Canada, 1999 and 2014; annual figures adjusted for 1851 to 1861 from Keyfitz, 1950; for 1861 to 1931 from McInnis, 2000a and 2000b; and for 1931 to 2014 from Statistics Canada, www.statcan.gc.ca/tables-tableaux/sum-som/101/cst01/demo03-eng-htm and CANSIM Table 051.004..

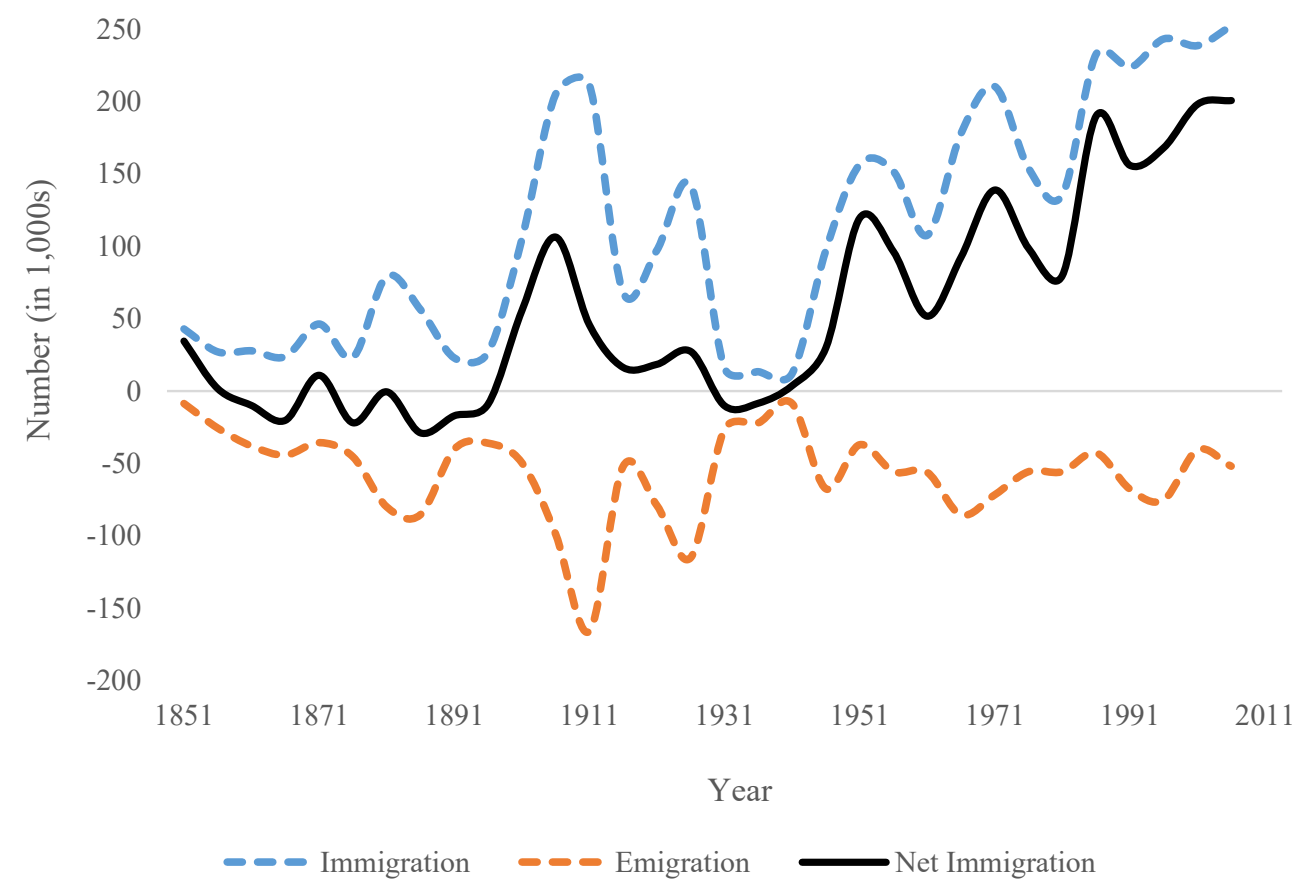

Figure 2. Five-year annual average international migration numbers (in 1,000s) for Canada, 1851-2011.

Source: Appendix Table 2, annual averages based on the beginning of each 5-year period.. 
Immigration increased steadily in the decades after World War II because Canada enjoyed a high degree of political freedom and economic prosperity, compared with Europe and many other parts of the world. Available employment in the expanding manufacturing, resource, and construction sectors of the Canadian economy gave ample opportunities for a new wave of immigrants. The 1967 changes in immigration law, including the elimination of national preference policies that had favoured immigration from European countries, prompted further increases as Canada began to receive new immigrants from Asia and Latin America. After 1967, equal preference was given to applications from any country, evaluated based on a point system for individual characteristics (higher points were given to younger adults, persons who spoke English or French, and those having higher education or occupation skills needed in Canada).

Because Canada's population has grown considerably since 1851, it is important to consider the volume of immigration compared to population size in assessing the total impact of net immigration (see Figure 3, which shows international migration rates per 1,000 population at the beginning of each 5-year period). Since 1851, when Canada's population numbered 2.6 million, the population has increased thirteen-fold, to 34.5 million in 2011. Has immigration increased at a comparable rate? The answer is clearly no. As shown in Figure 3, immigration relative to population size is now about onethird of the peak levels in the first decade of the twentieth century. Immigration during the 1901-11 decade, for example, amounted to 27.6 per cent of the 1901 population. The comparable figure for 2001-11 is 8.3 per cent, or about one-third the 1901-11 rate. Relative net immigration levels are also lower than earlier in the 20th century. Net immigration during 2001-11 is 5.9 per cent of the population at the beginning of the decade, compared with 15.5 per cent during the 1901-11 decade. The relative differences are slightly larger for net immigration than for gross immigration alone, because of the higher levels of emigration (both in relative and absolute terms) early in the twentieth century.

40

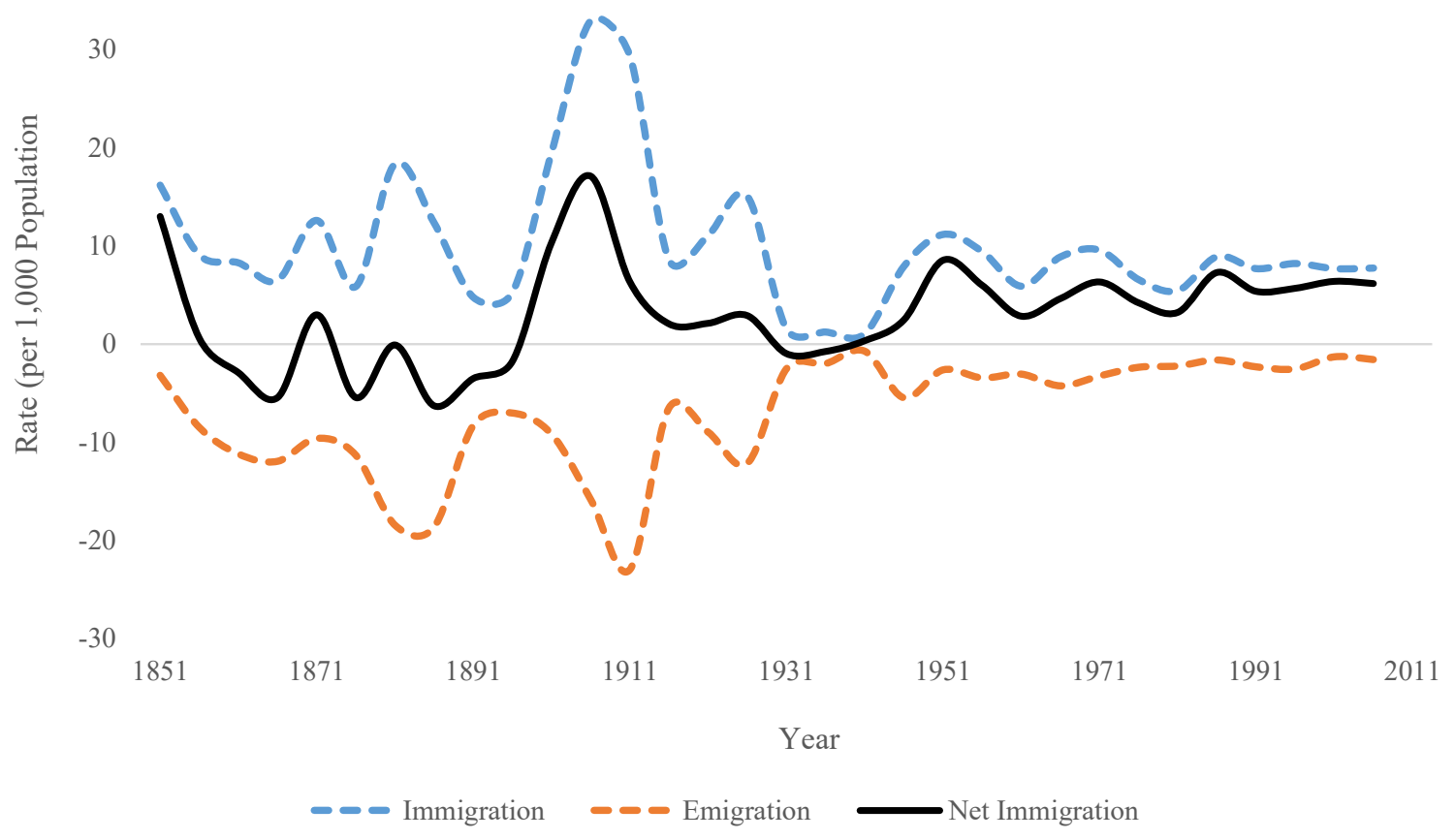

Figure 3. Five-year annual average international migration rates for Canada, 1851-2011 (rates are per 1,000 population at the beginning of the year).

Source: Appendix Table 2, annual average rates based on the beginning of each 5-year period. 


\section{Foreign-born population}

The 2011 census counted 6.8 million foreign-born residents in Canada. By comparison, the 1901 census enumerated less than one million foreign-born. The foreign-born population increased to 1.6 million in 1911, almost 2 million in 1921 and 2.3 million in 1931. The foreign-born population diminished during the Great Depression and World War II years, dropping to 2.1 million in 1951. Since then, the foreign-born population has grown steadily.

The lowest proportion of foreign-born was in 1901, when 13 per cent of Canada's population was foreign-born (see Figure 4). This proportion almost doubled, to 22 per cent, in 1931. With low immigration until after World War II, the foreign-born population decreased to less than 15 per cent in 1951. The proportion foreign-born has increased since 1951, to 16 per cent in 1961, 18 per cent in 2001 and 21 per cent in 2011.

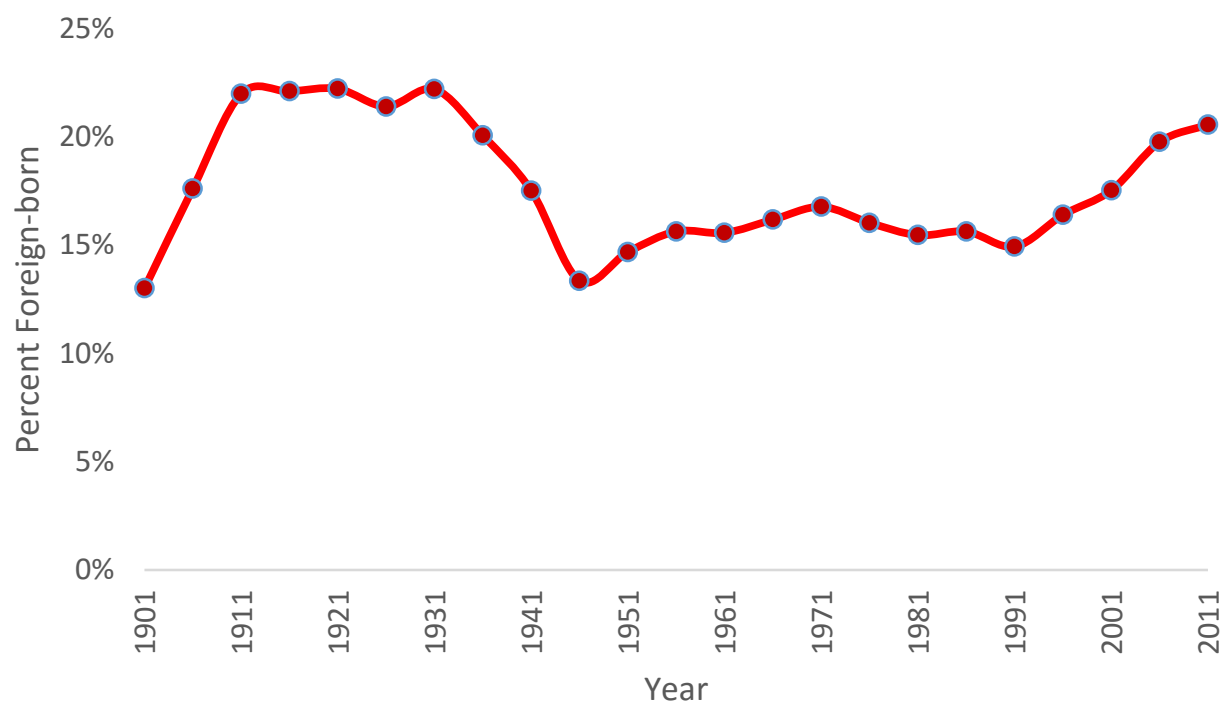

Figure 4. Per cent foreign-born for Canada, 1901-2011.

Sources: Statistics Canada, Number and share of the foreign-born population in Canada, 1901 to 2006, downloaded from http://www12.statcan.ca/census-recensement/2006/as-sa/97-557/figures/ c1-eng.cfm; Statistics Canada, 2011 National Household Survey microdata sample.

\section{Emigration trends}

Immigration has had a considerable impact on population growth in Canada during the past 160 years. To fully appreciate the overall influence of immigration, however, it is necessary to take into account the effect of emigration as well as immigration. Emigration offsets the population gains stemming from immigration. Moreover, the number of emigrants has changed substantially since 1851.

As shown in Figures 2 and 3, emigration reached a peak of 150,000 per year around 1911, and another peak of 100,000 per year in the late 1920s. As discussed below, the first period of high emigration from 1901 to 1931 was characterized by large flows of Canadian-born residents, while the second period from 1931 to 1941 witnessed both returning emigration of European-origin immigrants as well as some emigration of Canadian-born residents to the United States. Current levels of emigration are now lower, both in numerical and percentage terms. There were about 460,000 emigrants during the 2001-11 decade. As a result, the gains from net immigration today are almost twice 
as large as in the first decade of the 20th century. In the decade ending in 1911, there were 1,550,000 immigrants and 740,000 emigrants, producing a net immigration of 810,000 . For the decade ending in 2011, there were almost 2,457,000 immigrants and 462,000 emigrants, yielding a net immigration gain of 1,995,000, more than twice as high as the net immigration for 1901-11. Thus, compared with early in the 20th century, immigration levels are moderately higher, emigration is considerably lower, and net immigration is twice as large.

Past discussion of Canada's emigration trends has largely focussed on overall emigration. It is of some interest to also examine the distinctive trends in emigration separately for the foreign- and Canadian-born. ${ }^{3}$ Both the foreign-born and Canadian-born might depart Canada because of better prospects in other countries. The two groups, however, have different backgrounds and are likely to emigrate for different reasons. Some immigrants to Canada learn that they prefer living in their home country after experiencing Canadian residence. Other immigrants do not find suitable employment and learn after arrival that their prospects are better in their home country. This type of emigration is most common among recently arrived immigrants. Canadian-born people may decide to visit or study in other countries, particularly in the United States, and establish social networks there that lead to employment opportunities. Canadian-born residents may also emigrate because of marriage to someone in another country.

The number of emigrants by nativity reveals striking difference in the periods before and after 1931 (as shown in Figure 5). Prior to about 1931, the largest number of emigrants were

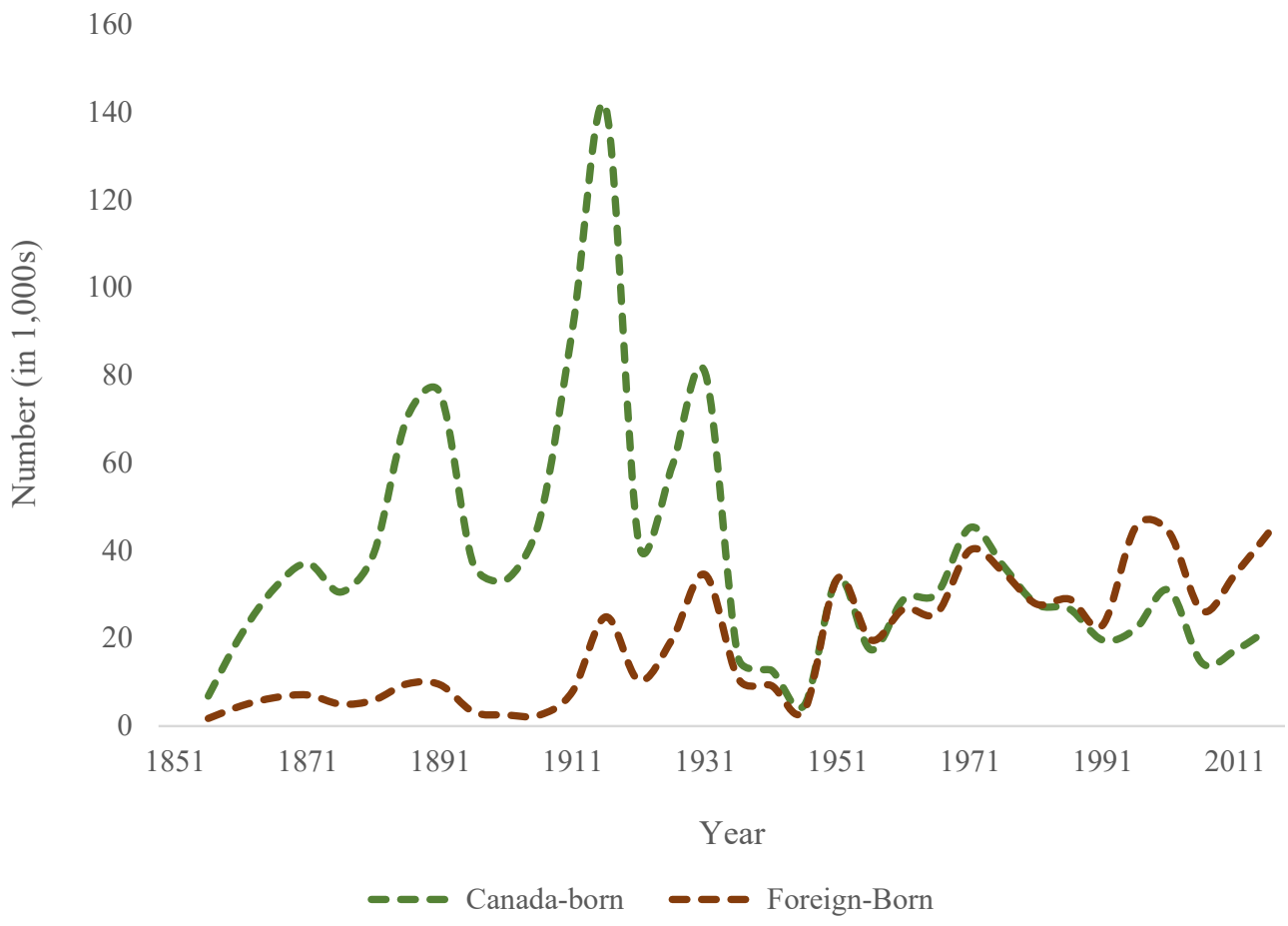

Figure 5. Five-year annual average emigration numbers (in 1,000s) by nativity for Canada, 1851-2011.

Source: Appendix Table 2, annual averages based on the beginning of each 5-year period.

3. As explained in the Appendix, this paper presents historical estimates of emigration for the foreign-born and Canadian-born for 1851 to 2011. Previous emigration estimates are limited to the total population. 
Canadian-born, with a heavy flow of emigrants to the United States in the late 1800s and early 1900s, when there was rapid industrialization in the northeast and midwest regions of the United States. The emigration of Canadians to United States was particularly large during 1881 to 1914, reaching a peak of 140,000 annually in the first decade of the 1900s (Lavoie 1972). Emigration of the foreign-born was at a much lower level than the Canadian-born prior to 1931, with annual emigration levels usually less than 20,000 per year. Unlike Canadian-born emigrants, the foreignborn often returned to their home country, although some, like the Canadian-born, also moved to the United States.

Annual emigration numbers for Canadian- and foreign-born were similar between 1931 and 1981, with 20,000 to 40,000 annual emigrants for each of the two nativity groups. Since 1981, emigration has become larger for the foreign-born than the Canadian-born. In recent years, about 20,000 Canadian-born and 40,000 foreign-born emigrate annually.

In addition, because the relative sizes of the Canadian-born and foreign-born population vary over time, it is useful to further examine emigration rates for each group. Figure 6 presents data on trends in emigration rates, per 1,000 population, over time by nativity. Although emigration rates were somewhat higher for the Canadian-born than the foreign-born prior to about 1911, the differences in emigration rates differ much less than the number of emigrants. Because the foreign-born population was relatively small in the 1800 s, even if emigration rates were similar to those for the Canadian-born, it would produce a comparatively small number of emigrants. Since about 1941, the emigration rate for the Canadian-born has remained relatively low, ranging between 0.5 and 2.0 per 1,000 population. The emigration rate for the foreign-born has fluctuated considerably during the past fifty years. In recent years, the emigration rate for the foreign-born has been about 6 per 1,000, much higher than the emigration rate for Canadian-born residents.

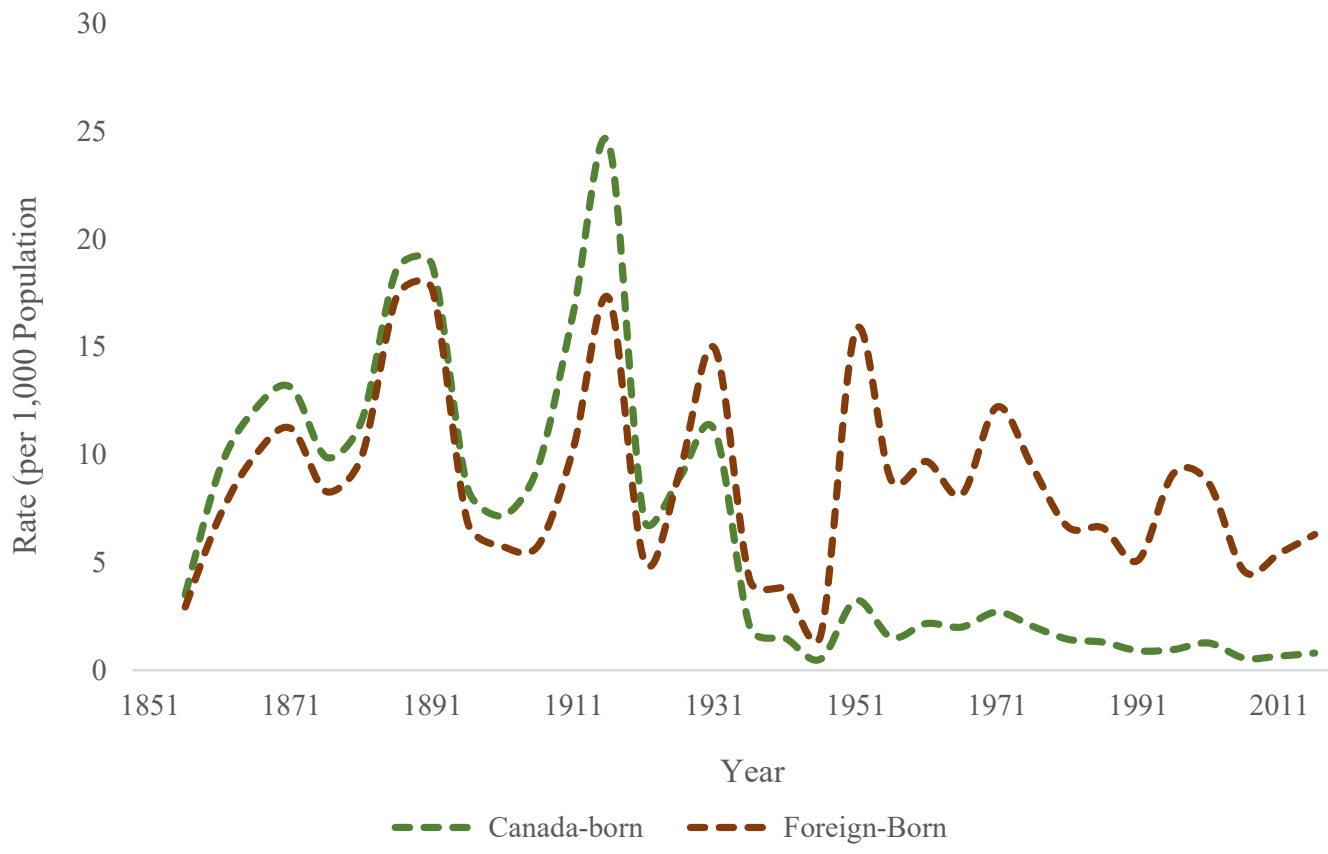

Figure 6. Five-Year annual average emigration rates for Canada by nativity, 1851-2011 (rates are per 1,000 population at the beginning of the year).

Source: Appendix Table 2, annual average rates based on the beginning of each 5-year period. 


\section{Current foreign-born population}

Immigration has injected large numbers of the foreign-born into the population of Canada. These immigrants come from many different nations. Some of these national groups are quite large, and become influential socially and politically in their settlement communities, while others are relatively small and are less noticeable.

Of the countries with one million or more foreign-born residents in 2013 (UNPD 2013; Tables 1 and 3), Australia has the highest proportion foreign-born (27.7 per cent), followed by New Zealand (25.1 per cent), Canada (20.7 per cent), Sweden (15.9 per cent), and Austria (15.7 per cent). ${ }^{4}$ Although the United States ranks sixth, with 14.3 per cent foreign-born, its foreign-born population numbered 45.8 million in 2013, and is more than the combined total foreign-born population (43.8 million) in the other top ten immigrant destinations.

This section examines the characteristics of Canada's foreign-born population, looking first at recently arrived immigrants (defined as immigrants who arrived within five years prior to the census), followed by data on the overall foreign-born population. Data on recently arrived immigrants illustrate trends in the flow of immigrants as they arrive in Canada. Data on the total foreign-born population document the characteristics of the stock of all immigrants.

\section{Recently arrived immigrants}

Table 1 displays demographic characteristics of non-immigrants and recently arrived immigrants in 1991, 2001, and 2011. ${ }^{5}$ Recently arrived immigrants are defined as foreign-born residents who arrived during the five years prior to the census date. With annual arrivals of about 250,000 immigrants and taking emigration into account, there were more than one million recently arrived immigrants enumerated in the 2011 population census.

Age, Sex, and Marital Status. The average age of recently arrived immigrants is about 30 years, indicating that the average age of arrival of immigrants is around 27 to 28 years, because recently arrived immigrants would have moved to Canada about two and a half years prior to the census, on average. Recently arrived immigrants are younger than non-immigrant Canadians. Canada's immigration system selects mainly immigrants in the early adult years, along with their children (if any). As a result, nearly one-half of recently arrived immigrants are aged 25 to 44 years. Another one-third of recently arrived immigrants are children and youth. Relatively few recently arrived immigrants are older than 65 years.

Most recently arrived immigrants are married or cohabiting, which was especially true in 2001 and 2011, when three-fourths of recently arrived immigrants are married, compared to slightly over 60 per cent of non-immigrants. Most recently arrived immigrant families report themselves as married or cohabiting couples, with relatively few living alone. Although not common, more recently arrived immigrants than non-immigrants are multiple families. Average family size is slightly larger for recently arrived immigrants than non-immigrants.

Housing. Recently arrived immigrants overwhelmingly reside in rental housing. Only about onethird of recently arrived immigrants own their house, compared to more than two-thirds of nonimmigrants. Research on homeownership trends (Edmonston and Lee 2013) suggests, however, that homeownership trajectories increase sharply for immigrants, and immigrant arrival cohorts achieve homeownership levels similar to non-immigrants after about 20 years of residence in Canada.

4. This listing excludes some smaller countries such as Switzerland and United Arab Emirates that have a high proportion of foreign-born residents, but have less than one million immigrants.

5. The most recent public-use census microdata are from the 2011 National Household Survey, which replaced the traditional long-form census questionnaire. Data for earlier years are from the census long-form questionnaire. 
Table 1. Demographic characteristics of non-immigrants and recent immigrants, 1991, 2001, and 2011

\begin{tabular}{|c|c|c|c|c|c|c|}
\hline \multirow[b]{2}{*}{ Characteristics } & \multicolumn{2}{|c|}{1991} & \multicolumn{2}{|c|}{2001} & \multicolumn{2}{|c|}{2011} \\
\hline & $\begin{array}{c}\text { Non- } \\
\text { immigrant }\end{array}$ & $\begin{array}{c}\text { Recent } \\
\text { immigrant }\end{array}$ & $\begin{array}{c}\text { Non- } \\
\text { immigrant }\end{array}$ & $\begin{array}{c}\text { Recent } \\
\text { immigrant }\end{array}$ & $\begin{array}{c}\text { Non- } \\
\text { immigrant }\end{array}$ & $\begin{array}{l}\text { Recent } \\
\text { immigrant }\end{array}$ \\
\hline Number $(1,000 \mathrm{~s})$ & 22,419 & 818 & 23,997 & 962 & 25,420 & 1,055 \\
\hline Average age & 32.5 & 29.8 & 34.8 & 29.9 & 37.0 & 30.3 \\
\hline Age groups $(\%)$ & 100 & 100 & 100 & 100 & 100 & 100 \\
\hline $0-14$ & 24 & 21 & 23 & 21 & 20 & 21 \\
\hline $15-24$ & 15 & 17 & 14 & 15 & 14 & 14 \\
\hline $25-44$ & 33 & 47 & 30 & 47 & 25 & 47 \\
\hline $45-64$ & 18 & 12 & 23 & 13 & 28 & 14 \\
\hline $65-84$ & 9 & 4 & 10 & 3 & 11 & 3 \\
\hline $85+$ & 1 & 0 & 1 & 0 & 1 & 0 \\
\hline Marital status $^{\mathrm{a}}(\%)$ & 100 & 100 & 100 & 100 & 100 & 100 \\
\hline Never married & 20 & 23 & 22 & 17 & 24 & 19 \\
\hline Married $^{\mathrm{b}}$ & 67 & 68 & 64 & 75 & 62 & 74 \\
\hline Other & 13 & 9 & 14 & 8 & 14 & 7 \\
\hline Family type $^{c}(\%)$ & 100 & 100 & 100 & 100 & 100 & 100 \\
\hline Married $^{b}$ & 62 & 65 & 59 & 68 & 59 & 71 \\
\hline Single parent & 9 & 10 & 10 & 8 & 11 & 7 \\
\hline Multiple families & 1 & 4 & 1 & 5 & 1 & 3 \\
\hline Living alone & 23 & 14 & 26 & 13 & 25 & 14 \\
\hline Other & 5 & 7 & 4 & 6 & 4 & 5 \\
\hline Average family size & 2.6 & 3.3 & 2.5 & 3.2 & 2.6 & 3.2 \\
\hline Housing tenure ${ }^{\mathrm{c}}(\%)$ & 100 & 100 & 100 & 100 & 100 & 100 \\
\hline Own & 63 & 30 & 66 & 31 & 72 & 36 \\
\hline Rent & 37 & 70 & 34 & 69 & 29 & 64 \\
\hline \multicolumn{7}{|l|}{ Family income $e^{\mathrm{c}, \mathrm{d}}$} \\
\hline Average & $\$ 71,200$ & $\$ 46,000$ & $\$ 76,900$ & $\$ 45,500$ & $\$ 75,200$ & $\$ 48,700$ \\
\hline$\% \$ 100,000+$ & 19 & 8 & 28 & 9 & 24 & 10 \\
\hline$\%$ Low-income ${ }^{\mathrm{e}}$ & 15 & 43 & 16 & 45 & 15 & 41 \\
\hline \multicolumn{7}{|c|}{$\begin{array}{l}\text { Note: "Recent immigrants" are defined as foreign-born who arrived in Canada within five years prior to } \\
\text { the census. } \\
\text { aPopulation aged } 20 \text { years and older. }\end{array}$} \\
\hline \multicolumn{7}{|c|}{ barried includes couples who are legally married or living in a common-law union. } \\
\hline \multicolumn{7}{|c|}{$\begin{array}{l}\text { 'For the household maintainer, the person designated as the primary contributor to household expenses, } \\
\text { who is aged } 25 \text { to } 64 \text { years. } \\
\text { dFamily income is in constant } 2006 \text { dollars. }\end{array}$} \\
\hline
\end{tabular}

Family Income. Family income of recently arrived immigrants is considerably lower than that of non-immigrants. In the 1991 to 2011 censuses, recently arrived immigrants report family incomes (in constant 2006 dollars) that are about two-thirds or less of non-immigrants' family incomes. Fewer recently arrived immigrants report family incomes of $\$ 100,000$ or more, compared to non-immigrants and more recently arrived immigrants report family incomes that are below Statistics Canada's low-income cut-off, again compared to non-immigrants.

Place of Settlement. Further information on social characteristics of non-immigrants and recently arrived immigrants is shown in Table 2. The initial place of settlement of immigrants in Canada is selective, with most immigrants choosing to reside in metropolitan areas in Ontario, Quebec, and British Columbia. Relative to the provincial population distribution of non-immigrants, a rela- 
tively high proportion of recently arrived immigrants decide to live in Ontario and British Columbia. Whereas, for example, 35 per cent of non-immigrants lived in Ontario in 2011, 43 per cent of recently arrived immigrants lived in Ontario. Several areas of Canada, especially the Atlantic provinces, receive relatively few immigrants.

Table 2. Social characteristics of non-immigrants and recent immigrants, 1991, 2001, and 2011

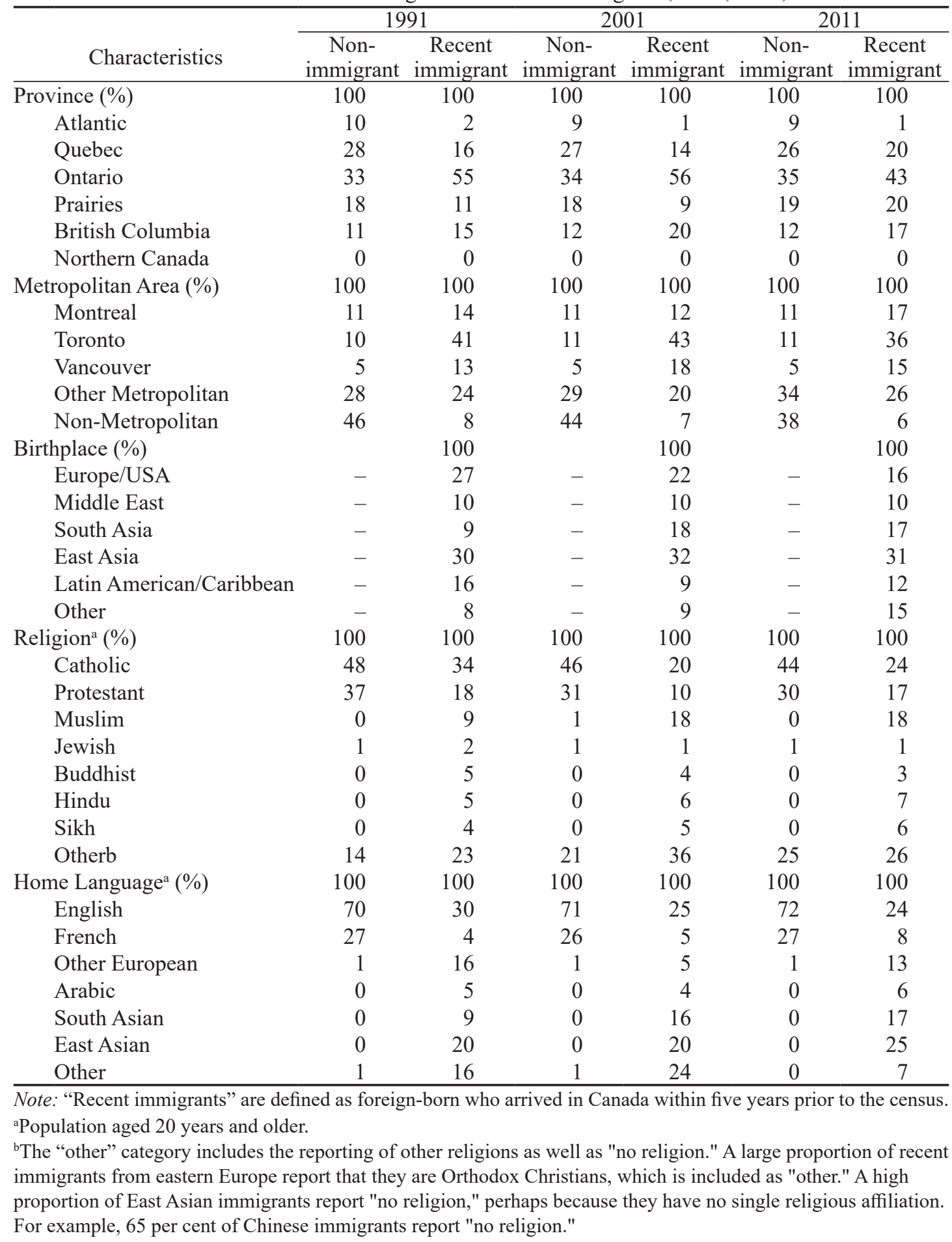


Recently arrived immigrants not only choose to settle in larger cities, a pattern similar to the United States and other large immigration destination countries, but are highly concentrated in Canada's three largest metropolitan areas: Toronto, Montreal, and Vancouver. These three metropolitan areas receive about three-fourths of all immigrants, and metropolitan Toronto alone received approximately 40 per cent of all newly arrived immigrants in recent decades. Comparatively few immigrants settle in smaller towns and rural areas. The concentration of Canadian immigrants in the three largest metropolitan areas differs from the United States, where immigrants are dispersed in many metropolitan areas and cities.

Place of birth. The birthplace of newly arrived immigrants has shifted in recent decades. The proportion of immigrants from Europe and the United States decreased, from 27 per cent in 1991 to 16 per cent in 2011. Immigrants born in the United Kingdom comprise about one-fourth of recent immigrants from Europe and the United States. The proportion of recently arrived immigrants from South Asia has steadily increased, growing from 9 per cent in 1991 to 17 per cent in 2011. Immigrants from East Asia make up the largest share of recently arrived immigrants, with Chinese immigrants comprising about one-half of East Asian immigrants. Immigrants from the Philippines are the second largest group of East Asian immigrants to Canada. Overall, East Asian immigrants comprised 31 per cent of all recently arrived immigrants in 2011. Smaller proportions of immigrants arrive from the Middle East, Latin America and the Caribbean, and other countries.

Religion. Every ten years, Canadian censuses include a question that asks residents about their religious affiliation. ${ }^{6}$ Compared to 1991, there were decreases in 2001 in the proportion of recently arrived immigrants who identified themselves as Catholic or Protestant, followed by modest increases in 2011. While 74 per cent of non-immigrants in 2011 were Christian (Catholic or Protestant), only 41 per cent of recently arrived immigrants were Christian. ${ }^{7}$ Relatively few non-immigrants in Canada identify themselves as Muslim, although the proportion of Muslim immigrants has increased from 9 per cent in 1991 to 18 per cent in 2011. Comparatively few non-immigrants and recently arrived immigrants identify themselves with other religious affiliations, such as Jewish, Buddhist, Hindu, or Sikh. A higher proportion of recently arrived immigrants identify themselves as "other" religion. ${ }^{8}$ Detailed inspection of data on religious affiliation reveals that a large proportion of recently arrived East Asian immigrants indicates "other" or "no religion." A high proportion of recently arrived immigrants from China selects "no religion," which may reflect that they have no specific religious preference or that they are reluctant to report their religious preference on a census questionnaire.

Language. More than 90 per cent of recently arrived immigrants to Canada report knowledge of English, French, or both. But a large proportion speaks languages other than English or French at home. Although 99 per cent of non-immigrants spoke English or French at home in 2011, only 32 per cent of recently arrived immigrants use either of the two official languages at home. Recently arrived immigrants in 2011 reported home languages that are other European languages (13 per cent, with Spanish, Italian, Portuguese, and Polish being most common), Arabic (6 per cent), South Asian languages (17 per cent, with Punjabi being most common), East Asian (25 per cent, with Chinese being most common), or some other languages (7 per cent).

6. The 2011 NHS questionnaire asked, "What is this person's religion?" and requested the respondent to state a specific denomination or religion, even if they were not currently an active member of that group.

7. Orthodox Christians are included in the "other" category. So, the overall percentage of respondents who are Christian is actually higher than only the sum of Catholics and Protestants.

8. For comparability over censuses, the "other" category includes respondents who reported either "no religion" or a religious affiliation that is not listed. 


\section{A profile of all immigrants}

The previous section limited out attention to recently arrived immigrants, those who arrived in Canada within five years of the census date. This section provides a profile of the overall foreignborn population, including education, income, language, place of residence, immigrant children and youth, and elderly immigrants. The tables in this section list 8 ethnic origin groups, including an "other" category for single-origins that are not included in the main 7 single-origin groups, as well as all respondents who reported multiple-origins. Notes on Table 3 provide more information about the ethnic origin categories presented in this section.

Table 3. Per cent with Bachelor's degree or higher for non-immigrants and immigrants, aged 25 to 64 years, by ethnic origin and sex, 1991, 1996, 2001, 2006 , and 2011

\begin{tabular}{lrrrrrr}
\hline & \multicolumn{3}{c}{ Men } & \multicolumn{3}{c}{ Women } \\
\cline { 2 - 7 } Nativity and ethnic origin & 1991 & 2001 & 2011 & 1991 & 2001 & 2011 \\
\hline Non-immigrant European & 18 & 15 & 17 & 16 & 15 & 21 \\
Immigrant & & & & & & \\
$\quad$ All immigrants & 28 & 30 & 38 & 22 & 24 & 34 \\
European & 21 & 22 & 28 & 16 & 17 & 28 \\
Arab & 45 & 22 & 45 & 29 & 30 & 40 \\
South Asian & 36 & 42 & 41 & 27 & 27 & 36 \\
Chinese & 38 & 35 & 48 & 25 & 29 & 39 \\
Other East Asian & 42 & 41 & 38 & 39 & 33 & 39 \\
Latin American & 27 & 38 & 26 & 23 & 16 & 27 \\
Black/Caribbean & 22 & 22 & 35 & 14 & 11 & 24 \\
Other & 38 & 20 & 40 & 31 & 30 & 38 \\
Ratio (Immigrant/Non-immigrant European) & times 100 & & & \\
All immigrants & 155 & 195 & 225 & 134 & 158 & 166 \\
European & 117 & 141 & 168 & 98 & 115 & 133 \\
Arab & 248 & 141 & 271 & 182 & 199 & 192 \\
South Asian & 201 & 277 & 243 & 166 & 183 & 173 \\
Chinese & 208 & 228 & 288 & 153 & 193 & 188 \\
Other East Asian & 230 & 268 & 226 & 239 & 218 & 186 \\
Latin American & 147 & 249 & 155 & 142 & 108 & 131 \\
Black/Caribbean & 122 & 143 & 207 & 89 & 74 & 116 \\
Other & 209 & 134 & 241 & 194 & 201 & 186 \\
\hline
\end{tabular}

Note: In order to have comparable ethnic-origin categories for the 1991, 2001, and 2011 censuses, using publicly available microdata samples, ethnic-origin is coded in the eight categories shown in this and following tables. Except for the "other" category, the ethnicorigin groups are for respondents who report themselves as single origin. For example, respondents who report themselves as Italian would be included in the European category. The "other" category includes persons reporting themselves as Aboriginal as well as the large number reporting multiple origins, such as English/Italian or Chinese/ Canadian/Irish. Some multiple origin adults report that all their origins are European. The "other" group includes the following sub-categories: Aboriginal (4.4 per cent), British and other (52.9 per cent), French and other (13.5 per cent), British, French, and other (8.3 per cent), and other multiple origins (20.9 per cent).

Education. Table 3 presents information on the percentage of immigrants and non-immigrants who have completed a university bachelor's degree. Non-immigrants of European origins are selected as the reference group in Table 3, shown in the top row. In 2011, 17 per cent of nonimmigrant males aged 25 to 64 years had completed a bachelor's degree, compared to 38 per cent 
Table 4. Mean family income of non-immigrants and immigrants by ethnic origin: 1991, 2001, and 2011

\begin{tabular}{llll}
\hline Nativity and ethnic origin & 1991 & 2001 & 2011 \\
\hline $\begin{array}{l}\text { Non-immigrant European } \\
\text { Immigrant }\end{array}$ & $\$ 70,000$ & $\$ 75,100$ & $\$ 73,100$ \\
All immigrants & $\$ 74,400$ & $\$ 73,200$ & $\$ 71,300$ \\
European & $\$ 79,200$ & $\$ 82,700$ & $\$ 80,600$ \\
Arab & $\$ 57,400$ & $\$ 55,700$ & $\$ 59,400$ \\
South Asian & $\$ 69,400$ & $\$ 67,200$ & $\$ 72,600$ \\
Chinese & $\$ 70,100$ & $\$ 66,000$ & $\$ 70,000$ \\
Other East Asian & $\$ 64,000$ & $\$ 62,100$ & $\$ 63,700$ \\
Latin American & $\$ 44,300$ & $\$ 54,200$ & $\$ 54,800$ \\
Black/Caribbean & $\$ 55,700$ & $\$ 56,400$ & $\$ 53,600$ \\
Other & $\$ 77,400$ & $\$ 81,500$ & $\$ 78,100$ \\
Ratio (Immigrant/Non-immigrant European) $\times 100$ & \\
All immigrants & 106 & 97 & 98 \\
European & 113 & 110 & 110 \\
Arab & 82 & 74 & 81 \\
South Asian & 99 & 89 & 99 \\
Chinese & 100 & 88 & 96 \\
Other East Asian & 91 & 83 & 87 \\
Latin American & 63 & 72 & 75 \\
Black/Caribbean & 80 & 75 & 73 \\
Other & 111 & 109 & 107 \\
\hline
\end{tabular}

Note: Family income is in 2006 constant dollars for families with a maintainer aged 25 to 64 years.

of immigrants. ${ }^{9}$ Overall, in 2011 immigrant males were more than twice as likely (2.25), compared to non-immigrant males, to have a bachelor's degree. For females in 2011, the ratio of immigrants to non-immigrants with a bachelor's degree was 1.66 .

The proportion with university degrees increased steadily from 1991 to 2011 for both male and female immigrants, reflecting Canada's immigration policy to select immigrants with advanced education. The proportion of immigrants with a bachelor's degree is higher for males, however, than females. There are variations by ethnic origin in the proportion of immigrants with bachelor's degrees. In general, Chinese, Arab, South Asian, other East Asian, and immigrants of "Other" ethnic origin are more likely to have completed university degrees. In 2011, 48 per cent of Chinese males and 45 per cent or more of Arab males, for example, had bachelor's degrees. European, Latin American, and Black/Caribbean immigrants are less likely to have bachelor's degrees than other immigrants. But all immigrant groups_-both males and females, except for Black/Caribbean females in 1991 and 2001 - are more likely to have bachelor's degrees than European-origin non-immigrants.

Income. Data presented in the previous section note that recently arrived immigrants have lower family incomes than non-immigrants. Table 4 presents information on average family income for all

9. Canada ranks relatively high among developed countries in the proportion of adults aged 25-64 years that have a university education (27 per cent in the 2011 census, which is similar to the figure of 28 per cent cited for Canada in OECD 2014). By nativity, 23 per cent of Canadian-born and 36 per cent of foreign-born adults have a university education. Among the Canadian-born, European-origin adults have lower rates (20 per cent) of university education than other ethnic origin groups, such as South Asians with 54 per cent and Chinese with 59 per cent. The lower university education levels of European-origin Canadian-born adults, who comprise about one-third of adults aged 25-64, reduces the overall levels of university education for Canada. 
Edmonston: Canada's immigration trends and patterns

Table 5. Per cent distribution of home language and knowledge of official languages for immigrants aged 25 to 64 years, by ethnic origin and sex, 1991, 2001, and 2011

\begin{tabular}{lrrrrrr}
\hline & \multicolumn{5}{c}{ Men } & \multicolumn{5}{c}{ Women } \\
\cline { 2 - 7 } Characteristic and ethnic origin & 1991 & 2001 & 2011 & 1991 & 2001 & 2011 \\
Home language is English or French (\%) & & & & & \\
All immigrants & 61 & 54 & 49 & 59 & 54 & 48 \\
European & 69 & 69 & 67 & 66 & 65 & 64 \\
Arab & 40 & 36 & 34 & 28 & 28 & 28 \\
South Asian & 42 & 36 & 33 & 41 & 38 & 32 \\
Chinese & 19 & 17 & 19 & 18 & 18 & 20 \\
Other East Asian & 24 & 26 & 28 & 34 & 36 & 36 \\
Latin American & 26 & 34 & 37 & 31 & 31 & 38 \\
Black/Caribbean & 88 & 80 & 72 & 91 & 80 & 74 \\
Other & 81 & 74 & 69 & 84 & 77 & 70 \\
Knowledge of official languages & (knows English, French, or both (\%) & & \\
All immigrants & 96 & 96 & 96 & 94 & 94 & 94 \\
European & 97 & 98 & 98 & 95 & 97 & 98 \\
Arab & 96 & 97 & 97 & 91 & 94 & 94 \\
South Asian & 97 & 97 & 96 & 91 & 91 & 92 \\
Chinese & 88 & 88 & 85 & 79 & 84 & 83 \\
Other East Asian & 95 & 96 & 96 & 93 & 94 & 95 \\
Latin American & 87 & 95 & 96 & 86 & 92 & 95 \\
Black/Caribbean & 100 & 100 & 100 & 99 & 99 & 99 \\
Other & 99 & 99 & 99 & 99 & 98 & 98 \\
\hline
\end{tabular}

immigrant families, by ethnic origin, for 1991 to 2011. In constant 2006 dollars, average family income increased for non-immigrants between 1991 and 2001, and then declined modestly between 2001 and 2011. For immigrants, however, average family income decreased in constant dollars throughout the 1991 to 2011 period.

Relative to non-immigrant families, immigrant families had slightly higher average family incomes in 1991. Immigrant family incomes relative to non-immigrant families dropped between 1991 and 2001 and rose slightly between 2001 and 2011, with 2001 and 2011 averages remaining below non-immigrant levels. This may be partially due to an increasing proportion of recently arrived immigrant families that, as shown in Table 1, have relatively low family incomes. Immigrant families that are European or "Other" ethnic origin have slightly higher average family incomes than nonimmigrant European-origin families. Arab, Latin American, and Black/Caribbean immigrant families are noticeable for having average family incomes that are relatively low (again, these figures may also be influenced by recently arrived immigrants with relatively low family incomes).

Language. Most immigrants to Canada know English, French, or both upon arrival in Canadamainly because their admission is based, in part, on knowledge of either of these, Canada's official languages. For the majority of immigrants, however, English or French is not their mother tongue, and many immigrants speak a language other than English or French at home. Table 5 presents information on home language and knowledge of official languages for immigrants by sex for 1991 to 2011.

Overall, there has been a sizeable decrease from 1991 to 2011 in the percentage of immigrants that report English or French as their home language. By 2011, about one-half of male or female immigrants reported that they speak English or French as their normal home language, compared to higher levels in preceding years. Some immigrant groups-including European, Black/Caribbean, and "Other" ethnic origins - are more likely to speak English or French at home, because a high 
proportion of European immigrants are from the United Kingdom and many Caribbean immigrants are from English-speaking countries. Most immigrant groups, however, are likely to speak languages other than English or French at home. A relatively high proportion of Chinese immigrants, more than 80 per cent, does not speak English or French at home. Likewise, most Arab, South Asian, other East Asian, and Latin American immigrants speak a language other than English or French at home.

A high proportion of immigrants reports that that they know English, French, or both. In 2011, 96 per cent of male immigrants and 94 per cent of female immigrants reported knowledge of official languages, which is about the same as reported in previous censuses. Knowledge of official languages exceeds 90 per cent for all ethnic origin groups, except for Chinese immigrants, who reported levels of 85 to 83 per cent for males and females, respectively, in 2011.

A higher proportion of males generally report knowledge of official languages. This is particularly apparent for three ethnic origin groups in which more males than females report knowing official languages: Arab males are 4 percentage points higher, South Asian males are 6 per cent points higher, and Chinese males are 5 percentage points higher than females, on average, for the 1991 to 2011 period.

Table 6. Provincial distribution of non-immigrant and immigrant families by ethnic origin, 2011

\begin{tabular}{lrrrrrr}
\hline & \multicolumn{6}{c}{ Region or province of residence } \\
\cline { 2 - 7 } Nativity and ethnic origin & Atlantic & Quebec & Ontario & Prairies & $\begin{array}{c}\text { British } \\
\text { Columbia }\end{array}$ & $\begin{array}{c}\text { Northern } \\
\text { Canada }\end{array}$ \\
\hline Non-immigrant & 9 & 29 & 32 & 18 & 12 & 0 \\
Immigrant & 1 & 16 & 53 & 13 & 17 & 0 \\
$\quad$ All immigrants & 1 & 16 & 57 & 11 & 15 & 0 \\
$\quad$ European & 2 & 27 & 50 & 9 & 12 & 0 \\
Arab & 0 & 5 & 64 & 13 & 18 & 0 \\
South Asian & 1 & 6 & 48 & 11 & 34 & 0 \\
Chinese & 0 & 10 & 45 & 21 & 24 & 0 \\
Other East Asian & 0 & 35 & 46 & 12 & 7 & 0 \\
Latin American & 0 & 37 & 52 & 9 & 2 & 0 \\
Black/Caribbean & 3 & 15 & 49 & 14 & 19 & 0 \\
Other & 11 & 55 & 166 & 72 & 144 & 0 \\
Ratio (Immigrant/Non-immigrant) times & 100 & & & & & \\
All immigrants & 14 & 55 & 178 & 61 & 127 & 33 \\
European & 22 & 93 & 156 & 50 & 102 & 0 \\
Arab & 3 & 17 & 200 & 72 & 153 & 0 \\
South Asian & 11 & 21 & 150 & 61 & 288 & 33 \\
Chinese & 0 & 34 & 141 & 117 & 203 & 33 \\
Other East Asian & 0 & 121 & 144 & 67 & 60 & 0 \\
Latin American & 0 & 128 & 163 & 50 & 19 & 0 \\
Black/Caribbean & 33 & 52 & 153 & 78 & 161 & 33 \\
$\quad$ Other & & & & & & \\
\hline
\end{tabular}

Place of Residence. Canada's population is not spread evenly across its vast territory. The population primarily lives in the southern area, within 200 kilometers of the border with the United States. Population density is low in the Atlantic provinces, the rocky Laurentian Plateau north of the Great Lakes, and the western mountains. Even fewer people live in the northern boreal forests and the far north. As shown in Table 6, more than one-half of non-immigrant families lives in either Quebec (29 per cent) or Ontario (32 per cent), with 9 per cent in the four Atlantic provinces, 18 per cent in the three Prairie provinces, and 12 per cent in British Columbia. 
Immigrants are even more selective in their spatial residence, with a greater proportion living in Ontario and British Columbia compared to non-immigrants. Immigrant families are 44 per cent more likely to live in British Columbia and 66 per cent more likely to settle in Ontario than nonimmigrants. Relatively fewer immigrants live in Quebec or the Prairie provinces. And comparatively few immigrants, compared to non-immigrants, live in the Atlantic provinces.

Immigrants of different ethnic origins vary in their provincial residence. Immigrants of European and "Other" ethnic origins are more likely to live in Ontario and British Columbia. Those of Arab and Latin American origins are more likely to reside in Quebec and Ontario. Immigrants of South Asian origin are more likely to live in Ontario, followed by British Columbia. Immigrants of Chinese and other East Asian origins are more likely to live in British Columbia, followed by Ontario. Other immigrants, for example, those of Black/Caribbean origins, are more likely to reside in Ontario.

As noted earlier, immigrants to Canada settle primarily in the larger metropolitan areas. Table 7 provides more detailed information on the metropolitan area distribution of immigrant families in 2011 compared to non-immigrant families. Most non-immigrants lived in either Montreal (12 per cent), Toronto (8 per cent), Vancouver (5 per cent), or other larger metropolitan areas ( 35 per cent), while 40 per cent of non-immigrant families were in smaller metropolitan areas, small towns, or rural areas.

Table 7. Metropolitan area distribution of non-immigrant and immigrant families by ethnic origin: 2011

\begin{tabular}{lrrrrr}
\hline & \multicolumn{5}{c}{ Metropolitan area of residence } \\
\cline { 2 - 6 } Nativity and ethnic origin & Montreal & Toronto & Vancouver & $\begin{array}{c}\text { Other major } \\
\text { metro }\end{array}$ & $\begin{array}{c}\text { Smaller } \\
\text { metro and } \\
\text { non-metro }\end{array}$ \\
\hline Non-immigrant & 12 & 8 & 5 & 35 & 40 \\
Immigrant & & & & & \\
$\quad$ All immigrants & 14 & 36 & 13 & 27 & 10 \\
European & 14 & 31 & 8 & 31 & 16 \\
Arab & 25 & 35 & 12 & 26 & 2 \\
South Asian & 5 & 56 & 14 & 22 & 3 \\
Chinese & 6 & 41 & 32 & 19 & 2 \\
Other East Asian & 10 & 36 & 22 & 28 & 4 \\
Latin American & 31 & 34 & 6 & 24 & 5 \\
Black/Caribbean & 34 & 42 & 2 & 20 & 2 \\
Other & 12 & 29 & 11 & 33 & 15 \\
Ratio (Immigrant/Non-immigrant) times & 100 & & & & \\
All immigrants & 116 & 439 & 277 & 77 & 25 \\
European & 116 & 378 & 168 & 89 & 40 \\
Arab & 207 & 427 & 255 & 74 & 5 \\
South Asian & 41 & 683 & 298 & 63 & 7 \\
Chinese & 52 & 501 & 683 & 54 & 4 \\
Other East Asian & 79 & 439 & 468 & 80 & 10 \\
Latin American & 256 & 415 & 132 & 69 & 11 \\
Black/Caribbean & 281 & 512 & 45 & 57 & 5 \\
Other & 99 & 354 & 234 & 94 & 38 \\
\hline
\end{tabular}

Immigrant families have a different metropolitan distribution than non-immigrants. Although about the same proportion of immigrants settles in Montreal, immigrants are more than 4 times more likely to live in Toronto and almost 3 times more likely to live in Vancouver than non-immigrants. Immigrants are less likely than non-immigrants to live in other metropolitan areas or nonmetropolitan areas. Arab, Latin American, and Black/Caribbean immigrant families are more likely 
to live in Montreal. This occurs to a large extent because these groups include immigrants from French-speaking areas of the Middle East and North Africa, East Africa, and Haiti and other Caribbean islands. Toronto attracts immigrant families of many ethnic origins, although there is striking preference for Toronto among South Asian, Chinese, and Black/Caribbean immigrants. Immigrants of South Asian, Chinese, and other East Asian origins have a marked preference for Vancouver, which is also attractive for other ethnic origin groups except for Black/Caribbean families.

Table 8. Social characteristics of immigrant and non-immigrant children and youth, aged 0 to 19, 2011

\begin{tabular}{|c|c|c|c|c|c|c|c|c|c|}
\hline \multirow[b]{2}{*}{ Characteristics } & \multicolumn{3}{|c|}{1991} & \multicolumn{3}{|c|}{2001} & \multicolumn{3}{|c|}{2011} \\
\hline & $\begin{array}{l}\text { All } \\
\text { children } \\
\text { and youth }\end{array}$ & $\begin{array}{l}\text { Immi- } \\
\text { grant }\end{array}$ & $\begin{array}{l}\text { Non- } \\
\text { immi- } \\
\text { grant }\end{array}$ & $\begin{array}{l}\text { All } \\
\text { children } \\
\text { and youth }\end{array}$ & $\begin{array}{l}\text { Immi- } \\
\text { grant }\end{array}$ & $\begin{array}{l}\text { Non- } \\
\text { immi- } \\
\text { grant }\end{array}$ & $\begin{array}{l}\text { All } \\
\text { children } \\
\text { and youth }\end{array}$ & $\begin{array}{l}\text { Immi- } \\
\text { grant }\end{array}$ & $\begin{array}{l}\text { Non- } \\
\text { immi- } \\
\text { grant }\end{array}$ \\
\hline Number $(1,000 \mathrm{~s})$ & 7,575 & 437 & 7,138 & 7,770 & 582 & 7,188 & 7,638 & 667 & 6,971 \\
\hline $\begin{array}{l}\text { Per cent immigrant } \\
\text { or non-immigrant } \\
\text { Age distribution }\end{array}$ & 100 & 6 & 94 & 100 & 7 & 93 & 100 & 9 & 91 \\
\hline $0-4$ & 100 & 2 & 98 & 100 & 3 & 97 & 100 & 3 & 97 \\
\hline $5-9$ & 100 & 5 & 95 & 100 & 6 & 94 & 100 & 8 & 92 \\
\hline $10-14$ & 100 & 7 & 93 & 100 & 9 & 91 & 100 & 11 & 89 \\
\hline $15-19$ & 100 & 9 & 91 & 100 & 12 & 88 & 100 & 12 & 88 \\
\hline Ethnic origin (\%) & 100 & 100 & 100 & 100 & 100 & 100 & 100 & 100 & 100 \\
\hline European & 51 & 30 & 52 & 39 & 19 & 41 & 30 & 13 & 32 \\
\hline Arab & 0 & 8 & 0 & 2 & 10 & 1 & 2 & 8 & 1 \\
\hline South Asian & 1 & 9 & 1 & 3 & 13 & 2 & 5 & 15 & 4 \\
\hline Chinese & 2 & 16 & 1 & 3 & 17 & 2 & 3 & 13 & 2 \\
\hline Other East Asian & 2 & 11 & 1 & 2 & 11 & 1 & 3 & 14 & 2 \\
\hline Latin American & 0 & 4 & 0 & 0 & 4 & 0 & 1 & 4 & 1 \\
\hline Black/Caribbean & 1 & 7 & 1 & 3 & 9 & 2 & 3 & 12 & 2 \\
\hline Other & 42 & 15 & 44 & 48 & 17 & 51 & 53 & 21 & 56 \\
\hline \multicolumn{10}{|c|}{ Per cent in low-income families } \\
\hline All immigrants & 17 & 37 & 16 & 19 & 41 & 17 & 17 & 34 & 15 \\
\hline European & 17 & 30 & 17 & 18 & 31 & 17 & 14 & 24 & 14 \\
\hline Arab & 54 & 62 & 34 & 49 & 57 & 42 & 42 & 51 & 35 \\
\hline South Asian & 21 & 33 & 15 & 29 & 44 & 21 & 24 & 34 & 21 \\
\hline Chinese & 27 & 39 & 15 & 31 & 46 & 21 & 28 & 38 & 22 \\
\hline Other East Asian & 27 & 36 & 21 & 33 & 43 & 25 & 25 & 33 & 20 \\
\hline Latin American & 47 & 50 & 42 & 38 & 40 & 35 & 31 & 41 & 27 \\
\hline Black/Caribbean & 42 & 46 & 40 & 47 & 53 & 45 & 39 & 46 & 35 \\
\hline Other & 14 & 32 & 14 & 15 & 30 & 15 & 14 & 25 & 14 \\
\hline
\end{tabular}

Immigrant children and youth. An increasing proportion of children and youth, aged 0 to 19 , are immigrants. ${ }^{10}$ In 2011, 9 per cent of children and youth were foreign-born, as shown in Table 8. The number of immigrant children and youth grew from 437,000 in 1991 to 667,000 in 2011.

Relatively few immigrant families arrive in Canada with very young children. As shown in Table 8 , there are relatively few children aged 0 to 4 years who are foreign-born. By the teen-age years, however, the proportion foreign-born increases to more than 10 per cent.

10. A high proportion of Canadian children and youth are sons and daughters, born in Canada, of immigrants. Although the characteristics and achievements of the 2nd immigrant generation are an important topic for study, we limit attention in this paper to foreign-born children and youth. 
Edmonston: Canada's immigration trends and patterns

Table 9. Demographic and social characteristics of immigrant and non-immigrant elderly, aged 65 years and older for females and males, 1991, 2001, and 2011

\begin{tabular}{|c|c|c|c|c|c|c|c|c|c|}
\hline \multirow[b]{2}{*}{ Characteristics } & \multicolumn{3}{|c|}{1991} & \multicolumn{3}{|c|}{2001} & \multicolumn{3}{|c|}{2011} \\
\hline & $\begin{array}{c}\text { All } \\
\text { elderly } \\
\text { adults }\end{array}$ & $\begin{array}{l}\text { Non- } \\
\text { immi- } \\
\text { grant }\end{array}$ & $\begin{array}{l}\text { Immi- } \\
\text { grant }\end{array}$ & $\begin{array}{c}\text { All } \\
\text { elderly } \\
\text { adults }\end{array}$ & $\begin{array}{c}\text { Non- } \\
\text { immi- } \\
\text { grant }\end{array}$ & $\begin{array}{l}\text { Immi- } \\
\text { grant }\end{array}$ & $\begin{array}{c}\text { All } \\
\text { elderly } \\
\text { adults }\end{array}$ & $\begin{array}{l}\text { Non- } \\
\text { immi- } \\
\text { grant }\end{array}$ & $\begin{array}{c}\text { Immi- } \\
\text { grant }\end{array}$ \\
\hline Number, both sexes $(1,000 \mathrm{~s})$ & 2,974 & 2,181 & 793 & 3,629 & $\begin{array}{c}2,591 \\
\text { Females }\end{array}$ & 1,038 & 4,593 & 3,221 & 1,372 \\
\hline Number $(1,000 \mathrm{~s})$ & 1,699 & 1,254 & 445 & 2,035 & 1,470 & 565 & 2,490 & 1,758 & 732 \\
\hline Age distribution (\%) & 100 & 100 & 100 & 100 & 100 & 100 & 100 & 100 & 100 \\
\hline $65-74$ & 61 & 62 & 58 & 55 & 55 & 55 & 56 & 57 & 54 \\
\hline $75-84$ & 32 & 32 & 31 & 36 & 36 & 36 & 33 & 33 & 34 \\
\hline $85+$ & 7 & 6 & 11 & 9 & 9 & 9 & 11 & 10 & 12 \\
\hline Marital status (\%) & 100 & 100 & 100 & 100 & 100 & 100 & 100 & 100 & 100 \\
\hline Never-married & 7 & 8 & 4 & 5 & 6 & 4 & 6 & 6 & 5 \\
\hline Married $^{a}$ & 44 & 44 & 44 & 45 & 44 & 47 & 50 & 50 & 49 \\
\hline Divored/Separated & 5 & 5 & 5 & 7 & 8 & 6 & 11 & 11 & 10 \\
\hline Widowed & 44 & 43 & 47 & 42 & 42 & 43 & 34 & 33 & 36 \\
\hline Family type (\%) & 100 & 100 & 100 & 100 & 100 & 100 & 100 & 100 & 100 \\
\hline Married $^{a}$ & 48 & 47 & 49 & 49 & 48 & 51 & 50 & 50 & 51 \\
\hline Single parent & 6 & 6 & 7 & 8 & 7 & 9 & 8 & 7 & 10 \\
\hline Multiple families & 2 & 1 & 5 & 3 & 1 & 7 & 4 & 2 & 9 \\
\hline Living alone & 38 & 39 & 34 & 37 & 39 & 31 & 35 & 38 & 28 \\
\hline Other & 6 & 7 & 5 & 4 & 5 & 2 & 3 & 3 & 2 \\
\hline Ethnic origin (\%) & 100 & 100 & 100 & 100 & 100 & 100 & 100 & 100 & 100 \\
\hline European & 80 & 80 & 79 & 66 & 66 & 65 & 56 & 57 & 52 \\
\hline Arab & 0 & 0 & 1 & 1 & 0 & 2 & 1 & 0 & 3 \\
\hline South Asian & 1 & 0 & 2 & 1 & 0 & 4 & 2 & 0 & 7 \\
\hline Chinese & 1 & 0 & 5 & 2 & 0 & 9 & 3 & 0 & 10 \\
\hline Other East Asian & 1 & 0 & 3 & 1 & 0 & 3 & 1 & 0 & 5 \\
\hline Latin American & 0 & 0 & 0 & 0 & 0 & 1 & 0 & 0 & 1 \\
\hline Black/Caribbean & 0 & 0 & 1 & 1 & 0 & 3 & 1 & 0 & 4 \\
\hline Other & 17 & 20 & 9 & 28 & 34 & 13 & 36 & 43 & 18 \\
\hline$\%$ in low-income families ${ }^{\mathrm{b}}$ & 23 & 22 & 26 & 22 & 22 & 23 & 16 & 15 & 18 \\
\hline
\end{tabular}

Note: a Married includes couples who are legally married or living in a common-law union.

b Statistics Canada calculates a low-income cutoff based on family size and composition. Shown here is the per cent of families below the low-income cutoff.

The ethnic origin of children and youth is quite different for immigrants and non-immigrants. Among non-immigrants, children and youth are primarily European or "Other" ethnic origins (usually multiple European origins). On the other hand, most immigrant youth are not European or "Other" ethnicities. As shown in Table 8, for 2011, the main ethnic groups among immigrant youth were South Asian (15 per cent), other East Asian (14 per cent), Chinese (13 per cent), Black/Caribbean (12 per cent), Arab (8 per cent), and Latin American (4 per cent).

An examination of data on the proportion of children and youth in low-income families reveals that immigrant as well as non-immigrant Arab, Black/Caribbean, and Latin American children are more likely to be in low-income families, although the proportion in low-income families is higher for immigrants than non-immigrants. For other ethnic origin groups, immigrant children and youth are more likely than comparable non-immigrants to be in low-income families.

Elderly immigrants. The arrival of immigrants from new origins in recent decades is beginning to affect the elderly population, as shown in Table 9, which presents information on the population 
aged 65 years and older for females and males for 1991 to 2011. The first panel of Table 9 shows information for immigrant females, and the second panel shows immigrant males. The immigrant elderly population grew from 793,000 in 1991 to 1,372,000 in 2011, increasing from 27 to 30 per cent of the overall elderly population. In 2011, the ratio was 114 elderly immigrant females $(732,000)$ to 100 elderly immigrant males $(640,000)$.

In 1991, immigrant females were noticeably older than non-immigrants, reflecting the large number of immigrants who arrived in Canada in the early 1900s. By 2011, the age distribution of elderly females was similar for both immigrants and non-immigrants.

There are no significant differences in marital status for older immigrant and non-immigrant females. There are differences, however, in their living arrangements. Immigrant elderly females are more likely to live in multiple family arrangements (mainly living with other relatives), and less likely to live alone.

The ethnic origin of elderly females illustrates changing levels over time. Although immigrant elderly females had predominantly European backgrounds in 1991, this has been steadily decreasing. By 2011, more immigrant elderly females reported themselves to be Chinese, South Asian, other East Asian, Black/Caribbean, Arab, and Latin American than previously. Changes in the proportion of the elderly population that are foreign-born, coupled with shifts in the ethnic origin of immigrants, is altering the ethnic composition of the overall elderly population.

Table 9 (cont'd).

\begin{tabular}{|c|c|c|c|c|c|c|c|c|c|}
\hline & & 1991 & & & 2001 & & & 2011 & \\
\hline Characteristics & $\begin{array}{c}\text { All } \\
\text { elderly } \\
\text { adults }\end{array}$ & $\begin{array}{l}\text { Non- } \\
\text { immi- } \\
\text { grant }\end{array}$ & $\begin{array}{c}\text { Immi- } \\
\text { grant }\end{array}$ & $\begin{array}{c}\text { All } \\
\text { elderly } \\
\text { adults }\end{array}$ & $\begin{array}{l}\text { Non- } \\
\text { immi- } \\
\text { grant } \\
\text { Males }\end{array}$ & $\begin{array}{l}\text { Immi- } \\
\text { grant }\end{array}$ & $\begin{array}{c}\text { All } \\
\text { elderly } \\
\text { adults }\end{array}$ & $\begin{array}{l}\text { Non- } \\
\text { immi- } \\
\text { grant }\end{array}$ & $\begin{array}{l}\text { Immi- } \\
\text { grant }\end{array}$ \\
\hline Number $(1,000 s)$ & 1,699 & 1,254 & 445 & 2,035 & 1,470 & 565 & 2,490 & 1,758 & 732 \\
\hline Age distribution (\%) & 100 & 100 & 100 & 100 & 100 & 100 & 100 & 100 & 100 \\
\hline $65-74$ & 61 & 62 & 58 & 55 & 55 & 55 & 56 & 57 & 54 \\
\hline $75-84$ & 32 & 32 & 31 & 36 & 36 & 36 & 33 & 33 & 34 \\
\hline $85+$ & 7 & 6 & 11 & 9 & 9 & 9 & 11 & 10 & 12 \\
\hline Marital status (\%) & 100 & 100 & 100 & 100 & 100 & 100 & 100 & 100 & 100 \\
\hline Never-married & 7 & 8 & 4 & 5 & 6 & 4 & 6 & 6 & 5 \\
\hline Married $^{\mathrm{a}}$ & 44 & 44 & 44 & 45 & 44 & 47 & 50 & 50 & 49 \\
\hline Divored/Separated & 5 & 5 & 5 & 7 & 8 & 6 & 11 & 11 & 10 \\
\hline Widowed & 44 & 43 & 47 & 42 & 42 & 43 & 34 & 33 & 36 \\
\hline Family type (\%) & 100 & 100 & 100 & 100 & 100 & 100 & 100 & 100 & 100 \\
\hline Married $^{\mathrm{a}}$ & 48 & 47 & 49 & 49 & 48 & 51 & 50 & 50 & 51 \\
\hline Single parent & 6 & 6 & 7 & 8 & 7 & 9 & 8 & 7 & 10 \\
\hline Multiple families & 2 & 1 & 5 & 3 & 1 & 7 & 4 & 2 & 9 \\
\hline Living alone & 38 & 39 & 34 & 37 & 39 & 31 & 35 & 38 & 28 \\
\hline Other & 6 & 7 & 5 & 4 & 5 & 2 & 3 & 3 & 2 \\
\hline Ethnic origin (\%) & 100 & 100 & 100 & 100 & 100 & 100 & 100 & 100 & 100 \\
\hline European & 80 & 80 & 79 & 66 & 66 & 65 & 56 & 57 & 52 \\
\hline Arab & 0 & 0 & 1 & 1 & 0 & 2 & 1 & 0 & 3 \\
\hline South Asian & 1 & 0 & 2 & 1 & 0 & 4 & 2 & 0 & 7 \\
\hline Chinese & 1 & 0 & 5 & 2 & 0 & 9 & 3 & 0 & 10 \\
\hline Other East Asian & 1 & 0 & 3 & 1 & 0 & 3 & 1 & 0 & 5 \\
\hline Latin American & 0 & 0 & 0 & 0 & 0 & 1 & 0 & 0 & 1 \\
\hline Black/Caribbean & 0 & 0 & 1 & 1 & 0 & 3 & 1 & 0 & 4 \\
\hline Other & 17 & 20 & 9 & 28 & 34 & 13 & 36 & 43 & 18 \\
\hline$\%$ in low-income families ${ }^{\mathrm{b}}$ & 23 & 22 & 26 & 22 & 22 & 23 & 16 & 15 & 18 \\
\hline
\end{tabular}


The second panel of Table 9 presents information for elderly males. Many of the patterns described for elderly females are similar for elderly males. The age distribution of elderly males is similar for immigrants and non-immigrants. Immigrant elderly males are more likely to live in multiple families and less likely to live alone, as is the case for immigrant elderly females. Immigrant elderly males, however, are more likely to be married than non-immigrant males. The ethnic origin of immigrant elderly males is changing over time, with a greater proportion of males reporting themselves as nonEuropean ethnic origins.

Changes in the proportion of the elderly population that is foreign-born, coupled with shifts in the ethnic origin of immigrants, are altering the ethnic composition of the overall elderly population, both females and males. Only 3 per cent of elderly adults reported themselves as not European or "other" in 1991; this percentage increased to 8 per cent for elderly females and 10 for elderly males in 2011, and will continue to increase in the next decades as large number of immigrants reach 65 years of age and contribute an increasing share of the elderly population.

\section{Immigrant integration}

In countries with large immigrant populations, researchers, policymakers, and the general public are understandably interested in the integration of newcomers. While many factors influence immigrant adjustment and integration (it is beyond the scope of this paper to discuss all these factors and the many dimensions of immigrant integration), two migration-related characteristics have notable effects that, while distinctive, can be overlapping: age at arrival and duration of residence. This section briefly highlights their role in Canadian immigrant integration.

\section{Age at arrival}

Immigrants to Canada arrive at different ages. The 2011 National Household Survey reported that of the 6.2 million immigrants, 35 per cent arrived as children or youths aged 18 years or younger.

Host Country Language Proficiency

Home Language is English or French

High School Completed

University Completed

Homeownership

Above the Low-Income Level

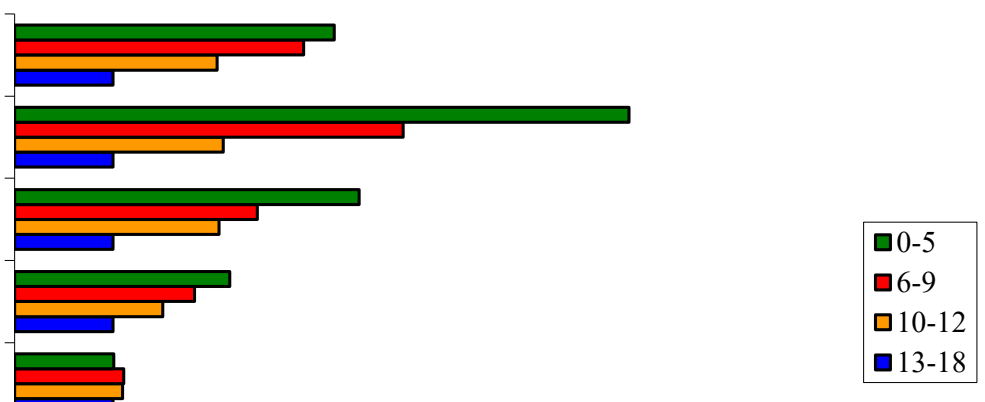

\section{White Collar Occupation}
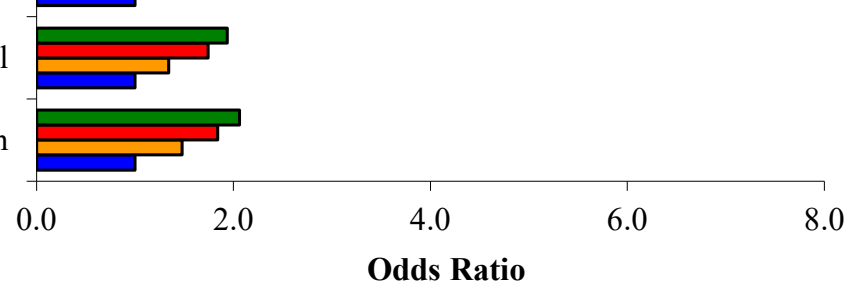

Figure 7. Odds ratios for status attainment relative to age at immigration of 13-18 years, for Asian immigrants aged 25 to 50 years in Canada, 2006.

Source: Lee and Edmonston 2011, Figure V. 
Age-at-arrival is considered a key factor in immigrant integration, given the central role of age in defining life-cycle stages, such as school attendance, entry into the labor force, and marriage and family formation. Cognitive capacities for mastering certain skills are also age-linked and hierarchical, meaning that learning progresses through successive stages. The early development of skills therefore influences the ability to master related and other skills later in life. For immigrants, age-atarrival is also related to duration of residence and years of experience in the host country, which has been shown in previous research to be important for outcomes such as employment, earnings, host country language proficiency, intermarriage, and homeownership (see Lee and Edmonston 2011 for a review of the research literature).

In a recent paper focusing on Asian immigrants in Canada, Lee and Edmonston (2011) calculate odds ratios for seven different outcomes for four age-at-arrival categories: 0 to 5 years, 6 to 9 years, 10 to 12 years, and 13 to 18 years, with the last category being the reference category. In all cases, the outcome variable is for adult immigrants aged 25 to 60 years in 2006, who arrived in Canada before their nineteenth birthday. The results are shown in Figure 7.

The most striking findings shown in Figure 7 are the differences between the reference category (Asian immigrants who arrived as teenagers between the ages of 13 and 18, which is shown with an odds ratio of 1.0 for each outcome variable) and Asian immigrants who arrived in Canada at ages younger than 6 (that is, who arrived between ages 0 and 5). The latter are much more likely to have English or French as their home language, to be proficient in at least one of Canada's official languages, to have completed high school or university, and to be in white-collar occupations. They are also more likely to be above the low-income cutoff. The only outcome where differences are small is homeownership.

While Asian immigrants who arrived at ages 6 to 12 years are more likely than those who arrived as teenagers to have odds ratios indicating better outcomes on these indicators, as shown in Figure 5, the differences are not as large and striking as those between the reference category and immigrants who arrived at ages younger than 6 . The differences are particularly large for three outcomes: host country language proficiency, home language, and high school completion. In summary, there is a strong effect of age-at-arrival—for immigrants arriving in Canada as children or youth—on many important measures of immigrant integration.

\section{Duration of residence}

Duration of residence is another key factor in immigrant adaptation. Analysis of duration of residence requires making a distinction between cross-sectional and longitudinal inferences. Shifts in age group differences over time reflect both aging and intercohort differences. Shifts in immigrant cohorts over time reflect both adaptation and intercohort differences. Based on a single survey or census, differences in immigrants based on duration of residence might be due to aging, adaptation, or intercohort effects.

In order to correctly disentangle processes of aging and immigrant adaptation, it is necessary to analyze data from two or more surveys or censuses using an appropriate statistical model. For this type of analysis, a double-cohort model is particularly useful. With immigrant cohorts nested within birth cohorts, this model includes three main variables—birth cohort, immigrant cohort, and period - as well as interaction terms between each of the three main variables. This model provides estimates for changes over time for a series of immigrant cohorts within birth cohorts, compared to similar birth cohorts of native-born residents. We illustrate the effects of duration of residence with results from a study on homeownership trends for Canadian immigrants (Edmonston and Lee 2013). 


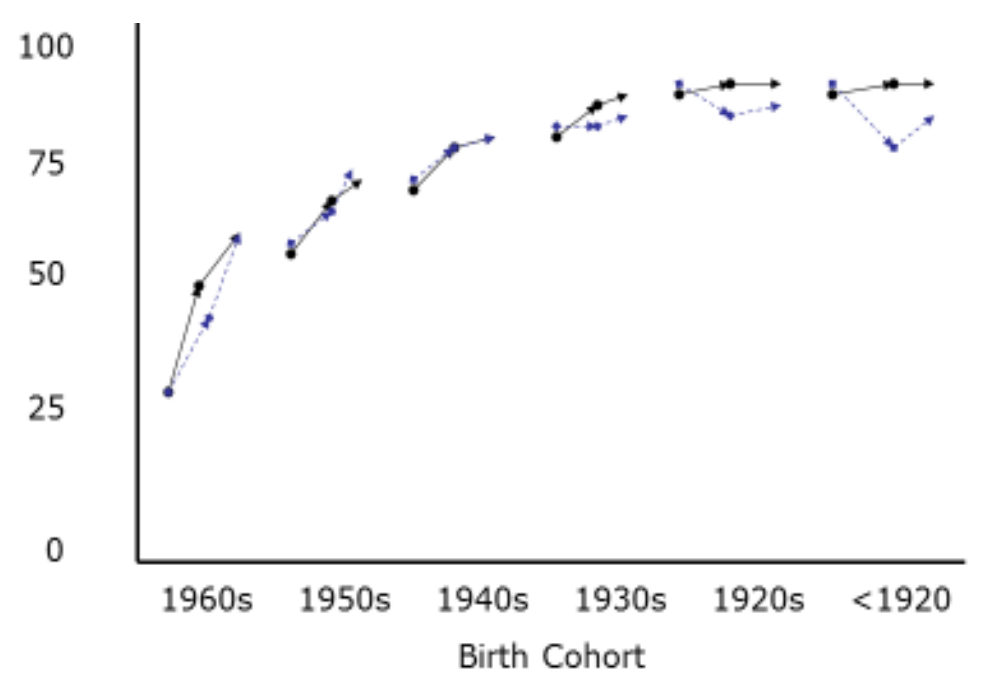

Figure 8. Homeownership trajectory plot for Canada-born residents and the 1970s immigrant cohort by birth cohort, 1991-96 and 1996-2001.

Source: Edmonston and Lee 2013, Figure 3.

Note: Per cent homeownership is shown on the vertical axis. Each birth cohort is shown for changes in per cent homeownership, with a solid circle and arrow, for change between 1991 and 1996, and between 1996 and 2001. Canada-born residents are show with solid lines, with trajectories that begin with solid circles. Immigrants are shown with dashed lines, with trajectories that begin with solid squares.

The effects of immigrant adaptation indicate the changes in homeownership for immigrant cohorts, within birth cohorts, over time. These effects can best be illustrated in a set of homeownership trajectory graphs that show changes in homeownership for immigrant cohorts, relative to Canadaborn residents, for similar birth cohorts.

We derive these trajectories by calculating the homeownership rates from logistic regression equations that include temporal, household, ethnic group, and place effects, evaluated at the mean category for the non-temporal variables.

Figure 8 shows the predicted per cent homeownership, holding all other factors constant, on the vertical axis. The horizontal axis shows the set of birth cohorts, with separate arrows in the figure displaying the change in homeownership for 1996 to 1996 and 1996 to 2001. Figure 8 shows homeownership trajectories for Canada-born households and the 1970s immigrant cohort (that is, all immigrants that arrived in Canada during 1971 to 1980). Canadian-born households present a picture of changes typically associated with life cycle changes: homeownership rates are low and quickly rising for younger householders, homeownership levels peak and stay steady for householders aged 50 to 70, and homeownership rates decrease slightly for older householders. The 1970s immigrant cohort resembles that for Canada-born householders, except for a notable decrease in homeownership rates for older householders - those born in the 1930s and earlier. Apparently, immigrants who arrived in Canada in the 1970s at age 40 and older (these would have been birth cohorts from the 1930s, 1920s, and 1920 and earlier) had stable or declining rates of homeownership during 1991-2001.

Overall, immigrant households display rapid gains in homeownership with longer residence in Canada. Among immigrant householders who have resided in Canada for 20 years or longer, homeownership rates are comparable with those for Canada-born householders. Edmonston and Lee (2013) report that more recent immigrant householders begin their housing careers with lower levels of homeownership. But even recent immigrants made rapid and remarkable gains in homeownership during the 1991 to 2001 period. 


\section{Demographic effects of immigration}

The preceding sections discussed trends and patterns of immigration, characteristics of immigrants, and highlighted the role of age at arrival and duration of residence on some aspects of immigrant integration. This section examines the contribution of immigration to Canada's population growth, including how immigration influences population changes (Edmonston 2010, 2014). Immigration affects a population demographically in two ways: directly, through the contribution of new members (immigrants) to the population, and indirectly, through future births to the immigrants and their descendants. To measure the first effect, we need to take into account net immigration (the number of immigrants minus the number of emigrants, as discussed in previous sections). To measure the second effect, we must examine the reproduction of the population after immigration. The effect of immigrants on future reproduction in a population is a function of their age and sex, levels of childbearing, and mortality rates. Determining their effect thus requires a population model that disaggregates the population by age, sex, and immigrant generation and takes into account four components of population change-immigration, emigration, fertility, and mortality.

From 1851 to 2011, the total population of Canada increased from 2.6 million to 34.3 million, or at an average annual rate of 1.6 per cent. Figure 9 displays the effect of immigration on the size of Canada's population for the period from 1851 to 2011. This graph shows the contribution of immigration to the population for five key immigrant cohorts: immigrants arriving in 1851-1901, 1901-31, 1931-51, 1951-71, and 1971-2011. The overall graph represents the growth of the total population from 1851 to 2011 . The bottom portion of the graph shows the hypothetical population size under conditions of no immigration since 1851. The different components in the upper portions of the graph show the population growth attributable to different waves of immigrants and their descendants.

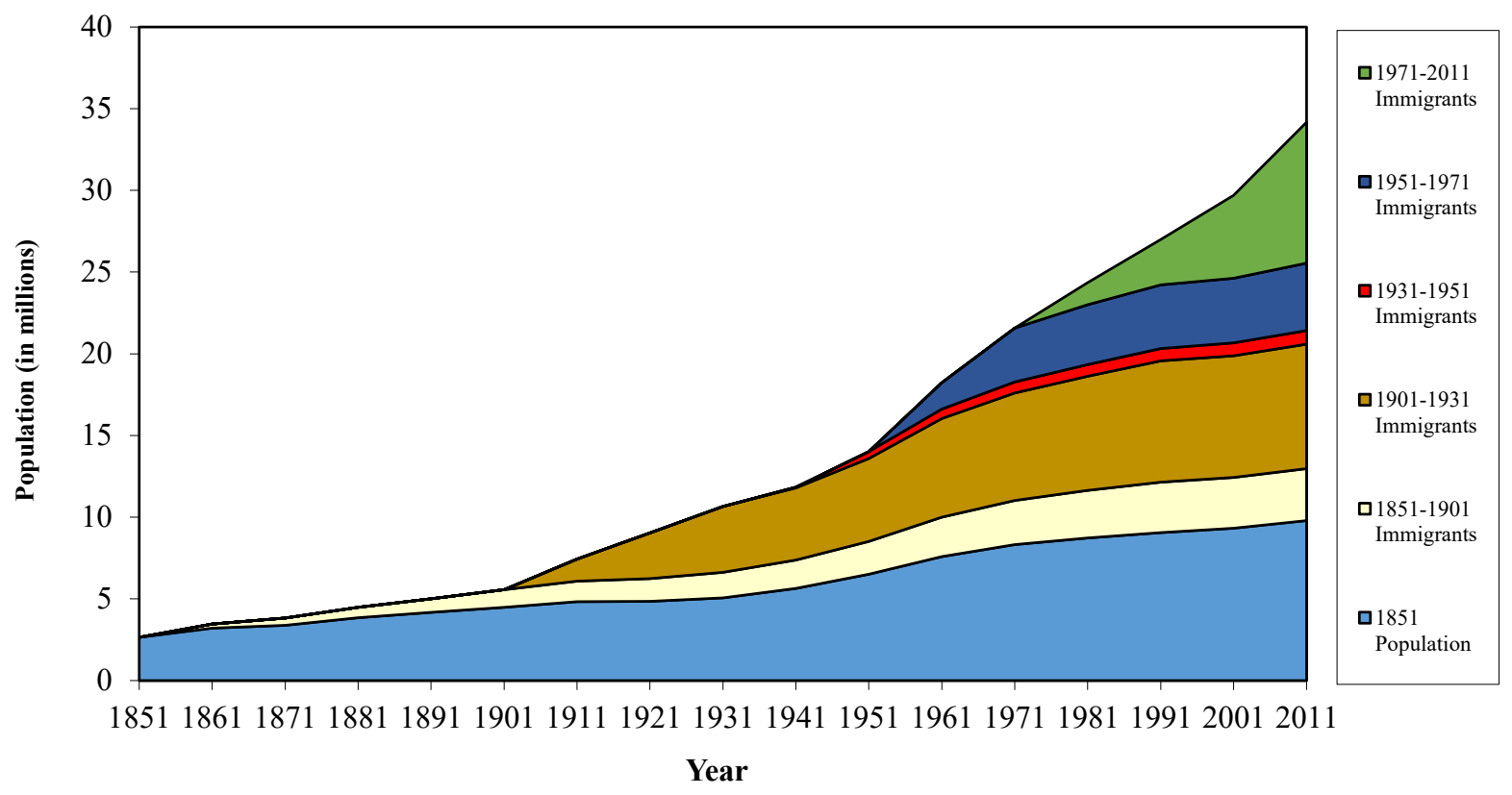

Figure 9. Demographic contribution of the 1851 population and selected immigrant entry cohorts to total population, Canada, 1851-2011.

Source: A historical reconstruction of Canada's population, as described in the Appendix. 
For this contrafactual population projection, the 1851 population is projected under the same fertility, mortality, and emigration conditions as the overall population projection. The population projection is cohort-based and does not explicitly indicate children born to possible unions of Canada-born and immigrant adults. Thus, for example, the contribution of the 1901-31 immigrant cohort is calculated by comparing the inclusion to the omission of immigration for 1901-31 — again, with the same fertility, mortality, and emigration conditions as the overall projection. Edmonston and Passel (1992) provide more discussion of the methods for immigrant generation projections, and Edmonston and Passel (1994) offer a comparable analysis of the contribution of immigrant cohorts to US population growth.

These numbers, derived from the historical reconstruction of Canada's population described in the Appendix, represent demographic constructs and are not genealogical derivations. For example, 25.1 per cent of Canada's population of 34.5 million in 2011, or about 8.6 million people, can be attributed to immigrants who entered the country since 1971 and their offspring (shown as the top band in Figure 9). These 8.6 million represents a demographic contrafactual answer to the question "If no immigration to Canada had occurred between 1971 and 2011 but emigration, fertility, and mortality had remained the same, how much smaller would Canada's population be in 2011?"

As shown in Figure 9, the 2011 Canada population would have numbered 9.8 million (or 29.2 per cent of the observed 2011 population) if there had been no immigration since 1851. In other words, Canada's 2.6 million residents in 1851 would have increased more than threefold, to 9.8 million in 2011. Migration in the latter half of the nineteenth century, from 1851 to 1901, was characterized by modest immigration and moderate emigration, and yielded net out-migration from Canada. All together, immigration during 1851-1901 contributed 3.2 million persons to the 2011 Canada population, or 9.3 per cent of the 2011 population. Immigration during the 1901-31 period contributed about 7.6 million people to the 2011 population, or 21.8 per cent of the total population. Immigration during 1931-51 provided a relatively small contribution, only 800,000 or 2.4 per cent of the total 2011 population. Immigration from 1951-71 contributed 4.1 million persons, or 12.4 per cent of the 2011 Canadian population.

Immigration during the last 40 years, from 1971 to 2011, has produced a slightly higher impact on the 2011 population than the first 30 years of this century. As of 2011, the post-1971 immigrant cohorts have had a larger overall effect-which will increase in future years — on Canada's population than selected earlier immigrant cohorts.

\section{Future prospects}

In this final section, we discuss the role of immigration for Canada's future population by looking at population projections and public attitudes toward immigration. We conclude with some summary comments on how immigration has and will continue to affect Canada's population.

\section{Population Projections}

Similarly to other national statistical agencies, Statistics Canada issues population projections that are revised every few years. These projections offer invaluable demographic information for the study of future population trends. Statistics Canada's (2010b) population projections are based on the 2009 population, with projections for Canada and its provinces to 2036. For the sake of concentrating on the effect of immigration, we assume a stable fertility level (a total fertility rate of 
1.7) and a slow gradual increase in life expectancy at birth. Statistics Canada's projections include three different immigration assumptions: a low rate of 6.0 annual immigrants per 1,000 population (implying 245,000 immigrants in 2036), a medium rate of 7.5 annual immigrants per 1,000 population (implying 334,000 immigrants in 2036), and a high rate of 9.0 annual immigrants per 1,000 population (implying 435,000 immigrants in 2036). Because Canada's immigration rate from 1991 has been, on average, close to 7.5 per 1,000, we focus on the assumption of a medium immigration rate for this paper.

Future immigration levels will have a major effect on Canada's future population growth. Canada's population size will grow from 33.7 million in 2009 to 43.8 million in 2036, a 30 per cent increase of 10.1 million. Annual population growth rates, however, will slacken from 1.2 per cent in 2009 to 0.8 per cent in 2036. Canada's future population growth will depend primarily on net immigration. Between 2008 and 2009, the population increased by 353,000, with 147,000 due to natural increase (the excess of births minus deaths) and 206,000 due to net immigration. Between 2035 and 2036 , the population is projected to increase by 342,000 , with natural increase accounting for 61,000 and net immigration accounting for 281,000 . Stated differently, 82 per cent of annual growth will be due to net immigration in 2036, compared to 58 per cent of annual growth in 2009.

Immigration will have modest effects on Canada's future age distribution. Although there will be important shifts in Canada's future age distribution, as noted below, there is only a one year difference in the 2036 median age distribution between the low and high immigration assumptions (Statistics Canada 2010b: 73). Overall, variations in immigration levels have a limited influence on the age distribution, compared to the larger relative effects of assumed fertility variations.

The population's median age increased from 30 years in 1981 to 40 years in 2009. With the advancing age of baby-boomers, the median age will continue to increase, to 44 years in 2036. Changes in the population's median age reflect changes in three major age groups: children and youth aged 0 to 14 years, older teenagers and adults aged 15 to 64 years, and older adults aged 65 years and older. The number of children and youth will continue to increase, growing from 5.9 million in 2009 to 6.9 million in 2036, but their percentage of the total population will decline, from 17.5 per cent to 15.8 per cent. The number of older teenagers and adults will increase from 22.7 million in 2009 to 26.8 million in 2036, while decreasing as a per cent of the total population from 67.4 per cent to 61.2 per cent. Only the elderly population will increase absolutely and relatively between 2009 and 2036, almost doubling from 5.1 million to 10.1 million, and increasing from 15.1 per cent of the 2009 population to 23.1 per cent of the 2036 population. The relative decrease of the population in the working-age group, 15 to 64 years, will alter Canada's dependency ratio, calculated as the number of children and youth plus number of elderly per 100 persons aged 15 to 64 years. In 2006, there were 24 children and youth plus 20 elderly per 100 persons in the working years, or a dependency ratio of 44 per 100 . By 2036, this ratio will increase to 26 children and youth plus 39 elderly per 100 persons in the working years, or a dependency ratio of 65 per 100. The demographic fact that there will be a 47 per cent increase in Canada's dependency ratio, with most of the increase occurring for the elderly population, underlies much of the concern about the country's future public finance policies, especially regarding public pensions and health care.

As discussed previously, most immigrants settle in Ontario and British Columbia, and interprovincial migration further reallocates Canada's population. Statistic Canada's (2010b) projections indicate that all provinces except Newfoundland and Labrador will increase their population between 2009 and 2036. The fastest population growth will occur in Ontario and British Columbia, which will increase their share of the national population. 
Changes in immigration will affect Canada ethnic and religious composition in future decades. Statistics Canada (2010c) has used innovative microsimulation methods to understand changes in the diversity of the population, projecting the 2006 base population forward to 2031. Staff relied on Statistics Canada's Demosim microsimulation model to project forward a 20 per cent sample of individuals in the 2006 population. Individuals in this type of demographic simulation experience fertility, mortality, and migration — using assumptions similar to those in Statistics Canada's standard cohort-component projections - as well as other transitions, such as change of education level, marital status, labour market participation and occupation, religion, and income.

The demographic microsimulation demonstrates three effects of immigration on Canada's population composition. First, there will be changes in the composition of the foreign-born population. In 1981, as shown in Figure 10, about two-thirds of the foreign-born population was from Europe. European-origin immigrants decreased to less than one-third of the foreign-born in 2011, and will decline further to one-in-five in 2031. Immigrants from Asia increased from 14 per cent in 1981 to 45 per cent in 2011, and will become more than one-half (55 per cent) of the foreign-born population in 2031. Immigrants from Africa will triple between 1981 and 2031, growing from 3 per cent to 9 per cent.

Secondly, changes in the composition of the foreign-born will be amplified by the addition of their children to the future population. Canada's visible minority population numbered 5.3 million, or 16 per cent of the total population. As a result of immigration and future births, the visible minority population will more than double by 2031, increasing to 12.9 million, or 31 per cent of the total population. The largest three visible minority groups currently are South Asian, Chinese, and Arabs, and these groups will continue to increase in absolute and relative size. South Asians will increase from 1.3 million in 2006 to 3.6 million in 2031; Chinese will grow from 1.3 million in 2006 to 2.7 million in 2031, and Arabs will increase from 300,000 in 2006 to 900,000 in 2031.

Finally, Statistics Canada's microsimulation work indicates immigration will increase religious diversity. Most Canadians reported themselves as Christian in 2006. But the proportion of Christians

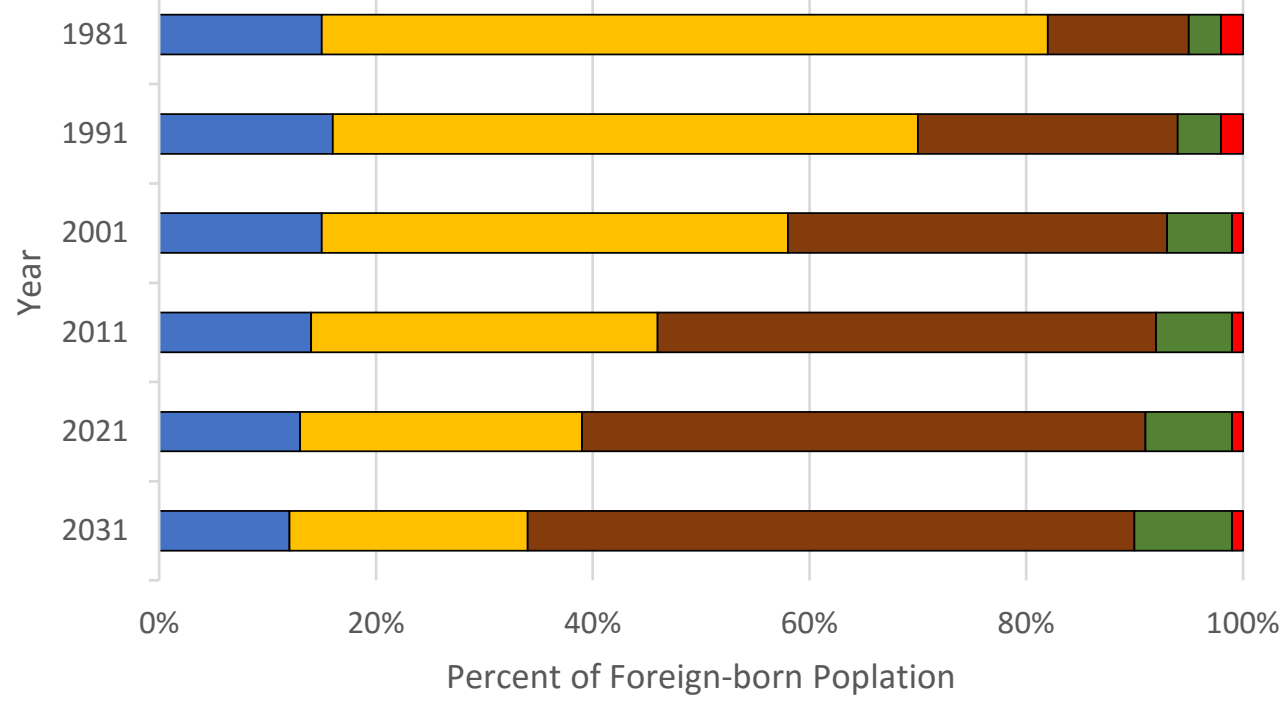

$$
\square \text { Americas } \square \text { Europe } \quad \square \text { Asia } \quad \square \text { Africa } \quad \square \text { Other }
$$

Figure 10. Composition of the foreign-born population by continent of birth, Canada, 1981 to 2031.

Source: Statistics Canada 2010c, Figure 2. 
is likely to decrease, from 75 per cent in 2006 to 65 per cent in 2031, as the non-Christian and nonreligious population increases. There were 2.5 million non-Christians in 2006, comprising 8 per cent of the population; this population will increase to 6.0 million in 2031, or 14 per cent of the population. In 2031, about one-half of non-Christians in Canada are expected to be Muslim.

\section{Public Opinion}

Canada is fortunate to have a long record of survey research on attitudes towards immigration. Environics, a public opinion survey company, has asked Canadians about their attitudes towards immigration in their Focus Canada Survey since 1977. One statement that has been regularly queried is, "Overall, there is too much immigration to Canada," with response choices being "strongly agree," "agree," "neither," "disagree," and "strongly disagree."11 An overall measure of public concern with Canada's immigration levels can be calculated by combining the responses for "strongly agree" and "agree" on this survey question. By this measure, 38 per cent of adult Canadians agreed or strongly agreed that there is too much immigration to Canada in the 2015 survey. Figure 11 shows public attitudes about the country's immigration levels for the period 1977 to 2015 . About 60 per cent or more of Canadians thought that immigration levels were too high from 1977 to the mid-1990s. After about 1995, public worries about too much immigration steadily decreased, to about one-third in 2005. During recent years, there have been slight increases in the percentage who are concerned about too much immigration, with the percentage agreeing or strongly agreeing with the survey question ran-

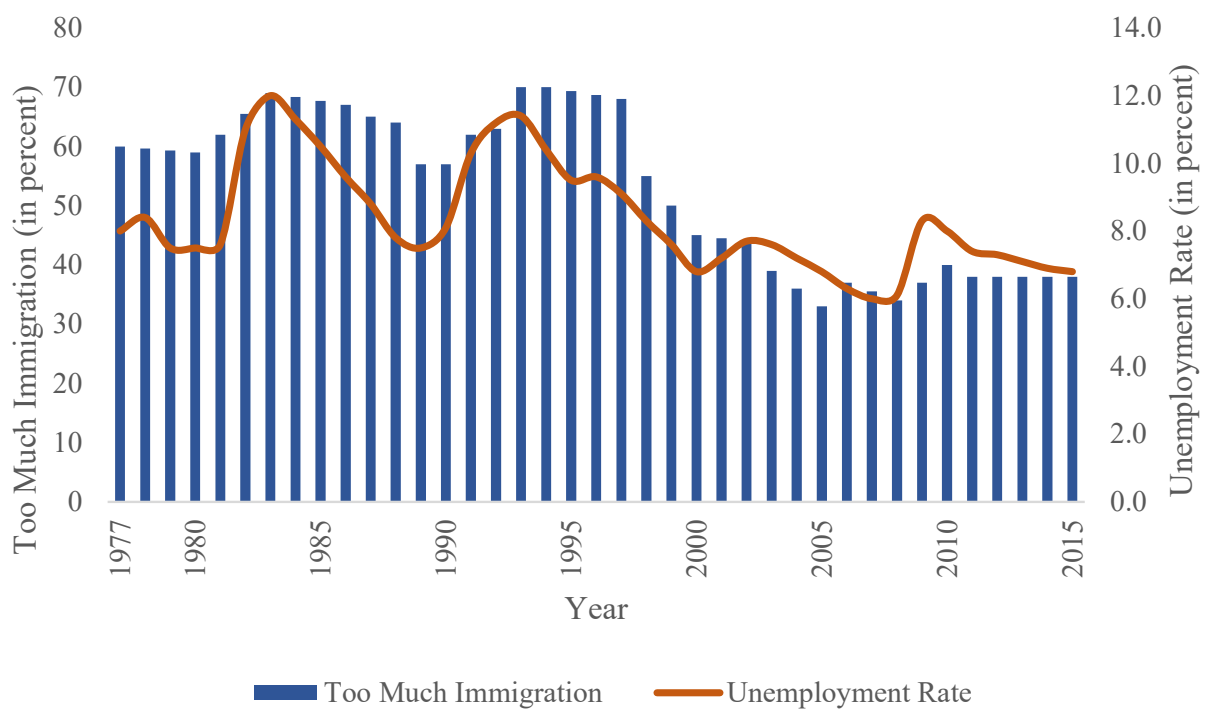

Figure 11. Relationship between Canada's unemployment rate and percentage agreeing or strongly agreeing with the statement "Overall, there is too much immigration to Canada," 1977-2012.

Sources: (1) Unemployment rates are from Statistics Canada, annual Labour Force Survey, downloaded from www.stats.gov.nl.ca/statistics/Labour/PDF/UnempRate.pdf, March 26, 2014; (2) Public attitudes on immigration are from Environics, Focus Canada Surveys, downloaded from www.queensu.ca/cora, March 26, 2014; see text for discussion of these data.

11. Environics first asked the survey question in 1977. The question has been included in annual Focus Canada Surveys, except for 1978, 1979, 1981, 1982, 1984, 1985, 1995, 1996, 1999, 2001, 2004, 2007, 2009, 2013, and 2014. In order to show trends over time, the responses for years with missing data are interpolated from the known data. 
ging between 34 to 40 per cent. However, these respondents remain a minority. Overall, Canadians offer broad support for immigration, generally believe that immigrant levels are at about the right level, and think that immigration has positive effects on the economy and society. This suggests that while immigration policies are dynamic, there is no strong public support for dramatic reductions in immigration to Canada.

Public attitudes about immigration levels are strongly affected by economic conditions. Figure 9 also displays the relationship between public attitudes about immigration and Canada's annual unemployment rates. When economic conditions deteriorate-and the unemployment rate increasespublic attitudes change, with a greater percentage expressing concerns that immigration levels are too high. Indeed, a simple regression equation for these data suggests that a one percentage point increase in the unemployment rate predicts a 6.6 percentage point increase in the proportion agreeing or strongly agreeing that there is too much immigration. ${ }^{12}$ It is likely that public support for immigration will remain generally positive, as long as Canada's economy is fairly strong.

\section{Concluding remarks}

Current immigration to Canada of about 250,000 new arrivals per year is similar to the peak levels of 1909-13, but also exceptional because they have continued for much of the past 25 years. The relative immigrant rate-about 9 immigrants per 1,000 resident population-is a considerably lower, however, than the 30 to 32 per 1,000 in earlier Canadian history, during 1909 to 1913. Absorbing large numbers of newcomers has costs as well as benefits. The costs are immediately apparent, but some of the benefits take longer to appear. Schools, hospitals, and social service agencies may have to arrange for language services and other special programmes for immigrants; however, most of the costs of these adjustments are paid by immigrants and their families. Immigrants have given up the familiarity of home in their quest for more rewarding careers and greater opportunities for their children. Immigrants must also contend with a receiving society that is ambivalent, and sometimes hostile, to their presence. The benefits of immigration are less apparent and more diffuse-lower costs and more diverse goods and services_-and appear over longer periods, as the children of immigrants complete their education, enter the labour force, and start to pay taxes.

Contemporary immigrants adapt and integrate to Canadian society-probably as fast as earlier waves of immigrants. Integration is not instantaneous, however, and the process is never complete, at least for adult immigrants. But for their Canadian-born children, and for those who arrive in Canada as young children, integration is a natural process that reflects immersion in Canadian schools and culture.

Immigrants and their children, however, are not the same as Canadian-born residents. In addition to many obvious characteristics such as language, religion, and cuisine, they generally differ on social and educational characteristics. Immigrants are also not representative of the society from which they come. Because of Canada's selective immigration policies, immigrants are not drawn from the least successful ranks of their home societies, but are generally well above average in terms of their education and other skills.

Perhaps the most important contribution of immigrants is their children. Many immigrants have made enormous sacrifices for their children's welfare, including the decision to settle in Canada.

12. This regression analysis is based on 39 data points for 1977 to 2015 . Readers should note as a caution: 15 data points for public attitudes are interpolated from known data. Nevertheless, the simple regression without imputed data points is similar, and is statistically significant at the 0.05 level. The R-squared value for the linear regression is 0.60 . 
Immigrant parents often have to work in multiple jobs, and sometimes in occupations well below the status they would have received if they had remained at home. These sacrifices have meaning, because immigrant parents believe that their children will have better educational and occupational opportunities in Canada than in their homelands. Immigrant parents push their children to excel by reminding them of their own sacrifices. These high expectations for the children of immigrants generally lead to high motivations for educational and occupational success.

Some cultural conservatives fear that immigrants will change Canadian character and identity. Yet, the definition of a Canadian national identity is elusive. Unlike many other societies, Canada does not have an identity tied to an ancient lineage. A key reason for a broad definition of Canadian identity is that the overwhelming majority of the Canadian population is descended from early English and French settlers as well as large waves of 19th- and 20th-century immigrants from many countries. Demographic estimates suggest that less than one-third of the 2011 Canadian population was descended from the mid-19th-century Canadian population (see Figure 7).

The Canadian experiment in nation-building is, in large part, the story of how immigrants have been absorbed into Canadian society, and how immigrants have enlarged and transformed Canada. Immigrants settled the western and northern frontiers; they participated in constructing canals, roads, and railroads; and they contributed significantly to the armed forces in Canada's wars. Immigrants provided much of the agricultural labour for the settlement of the prairies, and manufacturing labour for the Canadian industrial revolution, as well as a disproportionate share of the contemporary highly skilled scientists and engineers that are central to the modern economy. Most interestingly, immigrants and the children of immigrants have been among the most important creative artists who have shaped the development of the cultural arts, including movies, theatre, dance, and music.

Immigration is perhaps one of the most distinctive feature of Canadian history. Immigration has had a disproportionate effect on the demographic size, ethnic diversity, culture, and character of Canadian society. Immigrants and their children have integrated in Canada, but they have also shaped Canadian institutions in ways that have allowed strangers to participate in a new society.

Several common themes emerge in this paper. First of all, immigration takes many forms. The movement of South Asians to Toronto, Haitians to Montreal, Ukrainians to Manitoba, and Chinese to Vancouver have different causes and consequences. In most cases, the motivation for the immigrants is to improve their situation, usually by finding a better job or to obtain a better quality of life. Immigration to Canada certainly helps the immigrants and their families. Immigrants gain new skills, save money, learn new languages and ideas, and often start new businesses and create jobs in their new homes.

Second, immigration clearly affects Canadian society. Immigrants not only add new residents but also influence Canada's fertility and mortality. Because most immigrants are younger, their effects on fertility are especially important, because they contribute more births to the population than their numbers might suggest. A major demographic effect of immigration is the proportionately large number of children born in Canada, much larger than the number of foreign-born children and youth who arrive with their parents.

Third, discussion of current immigration in Canada requires a historical perspective. An honest appraisal of immigration over the past fifty years needs to acknowledge that immigration has not brought about the ethnic tensions and employment problems that some pessimists have predicted. Rather, the lives of millions of immigrants have been dramatically improved and immigrants have enriched Canada culturally and economically. To be sure, immigrants with low skills have competed with low-skilled domestic workers, and this has depressed wages for some. But low-skilled workers 
were already at risk because of technology improvements and, in some instances, competition from foreign goods. The appropriate public policy is to help low-skilled workers improve their job skills, not to reduce immigration, which might result in negative effects on the whole economy.

Finally, recent migration trends in Canada ensure that the population will continue to be reshaped by both international and internal migration. Long-term internal migration will continue, as people move from small towns and rural areas to larger towns and cities, and from less to more attractive areas, influenced by many factors, including economic opportunities. In addition, international migration will continue to be a powerful demographic force, as thousands of people arrive and alter Canada's population and society. Moreover, future immigration will not merely continue old patterns. For example, future immigration (and emigration) is likely to include a greater proportion of highly skilled workers who move between and within countries on a temporary basis. Immigration is likely to be more diverse in multiple ways, encompassing more categories of migrants and more varied forms of migration flows that will expand transnational migrant communities. Migration, by definition, is dynamic and fluid. We can be sure that future immigration in Canada will reveal new forms and new effects of this powerful demographic process.

\section{Acknowledgments}

I thank my colleague Sharon M. Lee and three anonymous reviewers for their helpful comments and constructive suggestions.

\section{References}

Beaujot, R., and M. Munib Raza. 2013. Population and immigration policy, in Canadian Studies in the New Millennium, edited by M. Kasoff and P. James. Toronto: University of Toronto Press.

Bélanger, A., and S. Gilbert. 2003. Immigrant women and their Canadian-born daughters, in Report on the Demographic Situation in Canada 2002, edited by A. Bélanger. Ottawa: Ministry of Industry, p. 127-51.

Bourbeau, R., and J. Légaré. 1982. Évolution de la mortalité an Canada et au Québec 1831-1931. Montreal: Les Presses de l'Université de Montréal.

Boyd, M. 2011. Immigrants in Canada: Trends and issues, in The Changing Canadian Population, edited by B. Edmonston and E. Fong. Montreal and Kingston: McGill-Queen's University Press.

Charbonneau, H. 1984. Trois siècle de depopulation amérindienne, Page 28-48 in L. Normandeau and V. Piche (editors), Les populations amérindienne et Inuit du Canada. Montréal: Les presses de l'Université de Montréal.

CIC (Citizenship and Immigration Canada). 1999. Citizenship and Immigration Statistics 1996. Catalogue No. MP22-1/1996. Ottawa: Ministry of Public Works.

. 2014. Facts and Figures 2014. Downloaded 10 December 2015 from www.cic.gc.ca/english/ resources/statistics/facts 2014/permanent/01.asp.

Edmonston, B. 2010. Measuring the effect of immigration on population growth, in Demographic Aspects of Migration, edited by T. Saltzmann, B. Edmonston, and J. Raymer. Amsterdam: Springer-Verlag.

- 2014. Two centuries of demographic change in Canada. Canadian Studies in Population 41(12):1-37. 
Edmonston, B., and S.M. Lee. 2013. Immigrants' transition to homeownership, 1991 to 2006. , Canadian Studies in Population 40(1-2; Special Issue on Lifecourse Perspectives on Immigration):57-74.

Edmonston, B., and M. Michalowski. 2003. International Migration, in The Methods and Materials of Demography, 2nd edn, edited by H. Shryock, J. Siegel, and D. Swanson. New York: Academic Press.

Edmonston, B., and J.S. Passel. 1992. Immigration and immigrant generations in population projections. International Journal of Forecasting 8:459-76.

1994. Immigration and race: Recent trends in immigration to the United States, in Immigration and Ethnicity: the Integration of America's Newest Arrivals, edited by B. Edmonston and J.S. Passel. Washington: The Urban Institute Press.

Henripin, J. 1972. Trends and Factors of Fertility in Canada. A 1961 Census Monograph. Ottawa: Statistics Canada.

Kerr, D., and R. Beaujot. 2010. Aboriginal demography, in Visions of the Heart: Canadian Aboriginal Issues, 3rd edn, edited by D. Long and O.P. Dickason. Toronto: Oxford University Press.

Lavoie, Y. 1972. L'émigration des Canadiens aux Ėtats-Unis avant 1930: Mesure du Phénomème. Montreal: Les Presses de L’Université de Montréal.

Lee, S.M., and B. Edmonston. 2011. Age-at-arrival's effects on Asian immigrants' socioeconomic outcomes in Canada and the United States. International Migration Review 45(3): 527-61.

Keyfitz, N. 1950. The growth of Canadian population. Population Studies 4:47-63.

McDougall, D.M. 1961. Immigration into Canada, 1851-1920. Canadian Journal of Economics and Political Science 27(May):162-75.

McInnis, M. 1994. Immigration and emigration: Canada in the late nineteenth century, in Migration and the International Labor Market 1850-1939, edited by T.J. Hatton and J.G. Williamson. London and New York: Routledge.

2000a. The population of Canada in the nineteenth century, in A Population History of North America edited by M.R. Haines and R.H. Steckel. Cambridge (UK): Cambridge University Press, p. 371-432.

2000b. The population of Canada in the twentieth century, in A Population History of North America, edited by M.R. Haines and R.H. Steckel. Cambridge (UK): Cambridge University Press, p. 529-99.

OECD (Organization of Economic Cooperation and Development). 2014. Education at a Glance 2014. Paris: OECD.

Simmons, A.B. 2010. Immigration and Canada: Global and Transnational Perspectives. Toronto: Canadian Scholars' Press.

Statistics Canada. 1965 Historical Statistics of Canada. Ottawa: Statistics Canada. 1994. Canada Year Book 1994. Ottawa: Ministry of Industry, Science, and Technology.

- 2010a. Canada's Demographic Estimates. Catalogue no. 91-C00-29. Ottawa: Ministry of Industry. . 2010b. Population Projections for Canada, Provinces and Territories: 2009 to 2036. Catalogue no. 91520-X. Ottawa: Ministry of Industry. 
Edmonston: Canada's immigration trends and patterns

- 2010c. Projections of the Diversity of the Canadian Population: 2006-2031. Catalogue no. 91-551-X.

Ottawa: Ministry of Industry.

—. 2011-14. Annual Demographic Estimates: Canada, Provinces and Territories. Catalogue no. 91-215-X.

Ottawa: Ministry of Industry.

UNDP (United Nations Population Division). 2013. International Migration Report 2013. New York:

United Nations.

\section{Appendix}

\section{International migration estimates for Canada}

This Appendix describes the data and methods for international migration estimates for Canada for the period 1851 to 2011. These estimates are based on previously published historical estimates for immigration and emigration. The historical international migration estimates are used in an immigrant generation population reconstruction model to estimate emigration separately for foreign-born and Canadian-born residents.

This work requires several steps: (1) a reconstruction of the 1851 population by nativity; (2) estimates of the 1851 to 1941 population that includes the population of Newfoundland, which was included in the 1951 and later censuses $;^{13}$ (3) new immigration and emigration estimates for 1871 to 1901 ; and (4) an immigrant generation population model to estimate international migration by nativity. Each step is discussed below, with a concluding section discussing the new international migration estimates.

\section{Reconstructing the 1851 population by nativity}

The first census for the national Census of Canada was conducted in 1851. It did not include an enumeration of Aboriginal peoples and did not distinguish between foreign-born and Canadianborn residents. The reconstruction of the 1851 Canadian population by nativity, excluding Aboriginal peoples, uses population counts from 1670 to 1851 from colonial censuses of England and France, as well as assumptions about fertility and mortality levels. Population counts for New France (Quebec) are available for 1670 and earlier years. English population censuses for the colonies of Nova Scotia and Newfoundland become available by 1680, New Brunswick by 1710, Prince Edward Island by 1740, Upper Canada (Ontario) by 1780, and Manitoba by 1800. English censuses of Nova Scotia provide separate counts for Acadians starting in 1700. Canada's population is reconstructed from 1670 to 1851 , assuming that the total fertility rate declined from 7.0 to 5.6, life expectancy for females improved from 39.0 to 43.4, life expectancy at birth for males increased from 38.5 to 42.4, and there were 1,000 annual emigrants during the period. These assumptions are based on available estimates of fertility, mortality, and emigration from research on Canada's colonial population. They imply annual net immigration levels of less than 1,000 for 1670 to 1781, higher net immigration of 3,000 to 4,000 annually during 1781 to 1801 (including net immigration of about 40,000 Loyalists during and

13. Newfoundland became the tenth province of Canada, changing its official name to Newfoundland and Labrador, on 31 March 1949. In common conversation, Newfoundland refers to the island and Labrador refers to the portion of the province that is on the Canadian mainland. 
following the U.S. War of Independence; McInnis 2000a: 375), and annual net immigration increasing to about 27,000 in the 1840 s. These net immigration estimates are similar to those commonly cited in historical population studies.

\section{Census populations for 1851 to 1951}

Two adjustments are made to the census population figures, to derive an estimated total population of Canada for the period from 1851 to 1951.

First, an estimate for the population of Newfoundland is added to the census counts for Canada for the 1851 to 1941 period, prior to Newfoundland joining Canada in 1949 and its inclusion in the 1951 census. This adjustment is made so that there is a consistent population over the 1851 to 2011 period for the population reconstruction. The population of Newfoundland is small relative to the Canadian total (about 2 to 4 per cent of the total during 1851 to 1941). English censuses of Newfoundland show population growth from 109,000 in 1851 to 361,416 in 1951. Any errors in the estimates for Newfoundland's population would have a comparatively minor impact on international migration estimates for the Canadian population.

Second, Dominion Bureau of Statistics research for the 1931 census of Canada (cited by Keyfitz 1950: 47) suggests that there may have been an undercount of about 100,000 native individuals in the 1851 and 1861 censuses. Allowing for this undercount, 100,000 is added to the census counts for 1851 and 1861. Keyfitz (1950: 47) estimates that 100,000 native persons were omitted in the 1851 and 1861 censuses, presumably in addition to some who were counted. Charbornneau (1984) suggests that the Aboriginal population numbered about 300,000 prior to European contact. But Kerr and Beaujot (2010) estimate that by the late 1800s, the Aboriginal population had declined to just 100,000.

If these two adjustments were not made to the census counts, the calculated Canadian population would be 8 per cent smaller for 1851 and 2 per cent smaller for 1941. The effect of not making these adjustments would be a modest reduction of emigration numbers for the population reconstruction.

\section{International migration estimates for 1871 to 1901}

Keyfitz (1950) prepared the first consistent set of international migration estimates for Canada. His work offers a careful review of available life tables and alternative mortality assumptions, surviving census populations by age and sex forward ten years, and estimating net international migration. Taking immigration estimates from official records, he derived emigration as a residual. His work is also useful for its analysis of the Canadian-born population in US censuses, and for providing the first Canadian emigration estimates. His work, conducted while at the Dominion Bureau of Statistics, was a forerunner of later estimates prepared by Statistics Canada. Statistics Canada (1965) revised and updated Keyfitz's pioneering estimates. Statistics Canada (1994, 2010, 2011-2014) provide international migration estimates for the period since 1965; these data are usually cited as Canada's "official" historical immigration estimates.

There is a serious problem of international transients to Canada being counted as immigrants in the immigration statistics for the late nineteenth century. Warnings about the overstatement of immigration numbers for the 1870 to 1900 period have been sounded by McDougall (1961) and McInnis (1994), as well as the Historical Statistics of Canada (Statistics Canada 1965: 11), where historian Kenneth Buckley notes that the immigration statistics are "grossly exaggerated from 1873 to 1891."

McDougall's (1961) work incorporated two important revisions. First, he argued that life tables derived from the US mortality experience are preferable for the study of Canadian mortality, rather 
than the English life tables used by Keyfitz. ${ }^{14}$ Second, he presented alternative immigration statistics, derived from information on emigration from Europe and the United States. A major limitation to official Canadian immigration data for the late nineteenth century is that the data do not distinguish between long-term immigrants and international transients. A substantial proportion of "immigrants" into Canada during the 1851 to 1901 period are persons who were in transit to the United States, or who resided in Canada for only a short period before moving to the US. Canadian immigration data for the late nineteenth century might more aptly be called arrival data.

McInnis's research addresses additional problems in the immigration and emigration data of the late nineteenth century, and provides new estimates. To emphasize the problems with "official" Canadian immigration data, McInnis writes:

In the decade 1871-80, the Canadian emigration rate of 109.3 (per 1,000 population; implied by official immigration numbers) is almost double that shown for Ireland, the European country with the highest rate. In the following decade the Canadian rate soared to 243.1, far higher than experienced by any European country. If we are to believe the conventionally used figures, the emigration from Canada in that decade [the 1880s] would have been equal to one-quarter of the whole population, at a time when about half of the population was under fifteen years of age. That is little short of astonishing, and compels one seriously to question the validity of the [immigration] data" (1994: 141).

McInnis's reassessment of immigration statistics includes a careful analysis of published records of Canadian immigration agents. He points out that counts of immigrant arrivals include several sources of misstatement: (a) along with transient passengers (arrivals in Canada who were destined for the United States), there were also persons ticketed for a Canadian destination who then travelled on to a final destination in the United States; (b) the reported immigration numbers for western inland ports probably missed many immigrants from the United States but also mistakenly included Canadians from Ontario who travelled west by a US route; (c) arrivals at the Niagara suspension bridge included many Canadians living in the United States who were making a visit home; and (d) arrivals at Pacific ports were reported after 1880, but included many arrivals who were probably not immigrants. After considering available information, McInnis suggests that it may be preferable to use available Canadian data on intercontinental arrivals for immigration analysis. Data on intercontinental arrivals count only arrivals at ocean ports (consisting of all European and Asian immigrants to Canada); such data do not count immigrants from the United States, but would include arrivals that were using Canada as a route to the United States. Even so, McInnis's opinion (1994: 148) is that data on intercontinental arrivals are probably an overstatement of Canadian immigration. Appendix Table 1 shows McInnis's revised figures on immigration for 1871 to 1901 as a starting basis for these new estimates, as well as this paper's estimates, which are discussed below.

\section{Immigrant generation population projection}

Immigrant generation population projections were proposed by Edmonston and Passel (1992) as a method for preparing national population projections by age, sex, and three immigrant generations: foreign-born (the 1st generation), sons and daughters of immigrants (the 2nd generation), and grandsons and granddaughters of immigrants as well as subsequent descendants (the 3rd and higher generation). The terminology for immigrant generations is commonly used in immigration research. It should be noted, however, that the individual description focuses on an ancestor who most recently

14. Some of the US life tables cited by McDougall (1961) were constructed in the 1950s and were not available to Keyfitz when he published his international migration estimates. 
Table A1. Estimates of international migration, Canada, 1871-1901 (numbers in 1000s)

\begin{tabular}{ccccc}
\hline Decade & CIC & Keyfitz & McDougall & $\begin{array}{c}\text { McInnis } \\
(2000 \mathrm{a})\end{array}$ \\
\hline \multicolumn{5}{c}{ Immigration } \\
$1871-1881$ & 343 & 353 & 253 & 350 \\
$1881-1891$ & 886 & 903 & 448 & 680 \\
$1891-1901$ & 339 & 326 & 249 & 250 \\
\multicolumn{5}{c}{ Emigration } \\
$1871-1881$ & $-^{\text {a }}$ & 438 & 293 & 404 \\
$1881-1891$ & $-^{\text {a }}$ & 1,108 & 602 & 826 \\
$1891-1901$ & $-^{\text {a }}$ & 507 & 364 & 380 \\
$1871-1881$ & - Net immigration $^{\text {a }}$ & -85 & -40 & -54 \\
$1881-1891$ & $-^{\text {a }}$ & -205 & -154 & -146 \\
$1891-1901$ & $-^{\text {a }}$ & -181 & -115 & -130 \\
\hline
\end{tabular}

Sources: CIC 1999; Keyfitz 1950: Table 11; McDougall 1961:

Table 3; McInnis 2000a: Table 9.3.

${ }^{a}$ not available.

arrived as an immigrant, rather than possible ancestors who arrived less recently. Also, Canada's Aboriginal population and many other Canadians, especially the French, have particularly long-standing residence in Canada. Given these qualifications, the immigrant generation model is most appropriately interpreted for immigrants, their children, and their grandchildren. The primary purpose of the model in this paper is a population reconstruction model that illuminates international migration and its demographic effects since 1851.

The data requirements for immigrant generation population projections are more demanding than standard national population projections, because data are required on fertility, mortality, and migration for each generation. Requiring such data for each generation has some advantages, however. For example, most standard national populations assume that immigrants acquire the fertility and mortality schedules of the resident population the instant they arrive, which is often unrealistic. Immigrant generation population projections have several advantages. Most importantly, they present estimates for the population by immigrant generations, showing the number and characteristics of the foreign-born and their descendants.

The immigrant generation population projection model is used for the historical reconstruction of Canada's population from 1851 to 2011. The population estimates and estimated components of change are derived using a modified cohort-component methodology to develop population estimates by age, sex, and immigrant generation. The model keeps track of three generations: the first generation, the second generation, and the third and higher generation. The data follow the designations used in Canadian censuses: an individual's generation is defined by the most recent immigrant ancestor. Thus, an individual with one immigrant parent and one Canadian-born parent is a member of the second immigrant generation.

The demographic model combines data on (a) fertility, mortality, immigration, and emigration for the total population from the consistent census correction estimates described above; and (b) data separate by immigration generation to produce population estimates for the total population of Canada, by immigrant generation. The basic strategy for the estimates involves fitting data on each of the four components (fertility, mortality, immigration, and emigration) to the series of population counts from the censuses of 1851 to 2011. The fitting involved an iterative process of progressively fitting the component series to the population targets. Because our interest is pri- 
marily in international migration, the targets for each date were the foreign-born population, the second-generation population (i.e., in census parlance, the Canadian-born population of foreign or mixed parentage), and the third-and-higher generation population (i.e., the Canadian-born of Canadian-born parentage).

Data from the following sources are used for the historical population reconstruction:

1) Age-sex population data are from Canadian population censuses from 1851 to 2011.

2) Mortality data are from two sources: (a) 1851 to 1941 survival values are based on comparable US life tables adjusted to fit life table expectancy at birth, by sex, values from Keyfitz (1950) and Bourbeau and Légaré (1982); and (b) 1951 to 2011 survival values are from Dominion Bureau of Statistics and Statistics Canada life tables.

3) Fertility data are primarily are Henripin (1972), with estimates of crude birth rates and agespecific fertility rates for the 1851 to 1951 period. Dominion Bureau of Statistics and Statistics Canada publications provide fertility estimates after 1951. Bélanger and Gilbert (2003) provide information on fertility levels by nativity for the 1961 to 2006 period.

4) Five-year immigration and emigration are from Keyfitz (1950) for 1851 to 1861; McInnis (2000a and 2000b) for 1861 to 1931, Statistics Canada (www.statcan.gc.ca/sum-som/101/cst01/ demo03-eng.htm) for 1931 to 2001; and Statistics Canada's CANSIM table 051.004 for 2001 to 2011. When data for 1851 to 1931 are available only for ten-year periods, five-year data are interpolated, based on the adjusted historical data on annual immigrant arrivals. The age-sex distribution of immigrants and emigrants for 1851 to 1941 are from Keyfitz (1950). Data on the age-sex distribution of international migration for more recent years are from Statistics Canada's (2010a, 2011-2013) Annual Demographic Statistics. These same immigration and emigration figures are also cited and described in Beaujot and Raza (2013).

It is important to note a significant difference between annual data on immigrant arrivals—as reported in Citizenship and Immigration Canada's data on legal permanent arrivals—and immigration data presented in publications of academic researchers or Statistics Canada. Summing Citizenship and Immigration Canada data for ten-year periods produces different numbers than the immigration totals cited in Keyfitz (1950), McInnis (2000a and 2000b), and Statistics Canada. For the 1991 to 2001 period, for example, Citizenship and Immigration Canada (2014) records 2,215,000 immigrant arrivals (rounding to the nearest 1,000) while Statistics Canada (2010a) reports immigration of 2,335,000, or 120,000 more. The difference occurs because immigration numbers reported by Statistics Canada and other national statistical offices include legal permanent immigrant arrivals as well as several other groups of persons who cross Canada's borders. Other than legal permanent immigrants, immigration numbers may also include non-immigrant aliens (such as students, foreign government officials, and temporary workers), returning Canadian government employees and military personnel and their families, arrivals of Canadians returning from foreign residence, and illegal entrants (Edmonston and Michalowski 2014: 462). This leads to a critical caution: There are sometimes large differences between annual immigrant arrival data recorded by Citizenship and Immigration Canada and the annual, five-year, or ten-year immigration data reported in publications by researchers and Statistics Canada. The immigration numbers in this paper, as discussed above and in the main text, are based on immigration arrival data reported by researchers and Statistics Canada, and include legal permanent immigrant arrivals as well as other persons who enter Canada for longer periods of residence.

As in a standard cohort-component projection, we begin with a population age $x$ at time $t, P_{x^{\prime}}^{t}$ survival rates for survival from age $x$ to $x+5$ during the period from $t$ to $t+5, S_{x}^{t, t+5}$, and age-specific 
fertility rates for women age $x$ at time $t, F_{x}^{t}$. We assume five-year age groups, so a population age $x$ represents the age group $x$ to $x+4$. To include international migration, we expand the basic model by defining immigrants age $x$ during the period $t$ to $t+5, I_{x}^{t, t+5}$, and emigrants age $x$ during the period $t$ to $E_{x}^{t, t+5}$. Then, net migrants during the period are defined as $N_{x}^{t, t+5}=I_{x}^{t, t+5}-E_{x}^{t, t+5}$. We assume that all demographic data and calculations are separate for males and females.

We add an immigrant generations index to the basic model. Consider a population indexed by $k$ generations, where $k=1,2$, and $3: k=1$ indicates the first generation, $k=2$ indicates the second, and $k=3$ indicates the third and higher generations. The survival of the population alive at the beginning of the projection period, for all age groups but the last, becomes:

$$
P_{x+5, k}^{t+5}=P_{x, k}^{t} S_{x, k}^{t, t+5}+\frac{N_{x, k}^{t, t+5}\left(1+S_{x, k}^{t, t+5}\right)+N_{x+5, k}^{t, t+5}\left(1+S_{x+5, k}^{t, t+5}\right)}{4}
$$

For the open-ended age category, the survival rates are adjusted to define the survival from the open-ended age category in one period to the open-ended age category in the next period.

In general, the number of immigrants by generation is non-zero for the first generation and zero for the second and higher generations; immigrants are rarely Canadian-born persons. On the other hand, the model makes apparent that emigrants by generation may have non-zero values for all generations. Hence, observed values of net migration by generation are usually positive for the first generation (representing net immigration of the foreign-born) and typically negative for the second and higher generations (indicating emigration of the Canadian-born).

In a female-dominant model, a mother in the $k$ th generation would produce an offspring in the $k+1$ st generation. We use the term female-dominant to mean that the model derives the generational characteristics of children from the mother. In other words, the generational membership of the father has no relevance for the offspring in the female dominant perspective. Since it is logically impossible for a mother to give birth to a foreign-born child while resident in Canada, the population aged 0 to 4 for the first generation derives solely from immigration.

The female-dominant model, however, needs to be modified to correspond to the most recent ancestor definition usually used in Canada censuses. It might be thought that a first-generation mother would give birth to a second-generation offspring, a second-generation mother would give birth to a third-generation offspring, and a third-plus mother would always give birth to a third-plus offspring. In actuality, a woman may have a partner who is not of the same immigrant generation. If a woman has a partner who has more recent immigrant ancestry, the offspring's immigrant generation will depend on the partner's immigrant generation, rather than on the mother. For example, if a third-plus generation woman has a child with an immigrant father, then the child (according to census definitions) will be reported as second-generation. This immigration generation effects can be including in a population projection model by incorporating a transition matrix that determines the immigrant generation of births from the joint immigrant generations of both mother and father.

Consider a matrix $G_{k, m}$, which indicates the proportion of births in the mth generation $(m=1,2,3)$ born to women in the $k$ th generation. In the female-dominant model, $G_{1,2}=G_{2,3}=G_{3,3}=1$, and all other cells in the $G$ matrix are zero. After modelling the generational membership for recent birth cohorts, the following $G$ matrix best fits the observed Canadian census data: $G_{1,2}=1.00, G_{2,2}=0.13$, $G_{2,3}=0.87, G_{3,2}=0.05, G_{3,3}=0.95$. 
Incorporating the $G$ matrix for the population in the first five years of life is:

$$
P_{0,4}^{t+5}=\sum_{k=1}^{3}\left[G_{k, m}\left(B_{k}^{t, t+5} \bullet \frac{S_{b, k}^{t, t+5}+S_{b, k+1}^{t, t+5}}{2}\right)\right]+\frac{N_{0,4}^{t, t+5}\left(1+S_{b, 4}^{t, t+5}\right)}{4}
$$

where $S_{b, k}^{t, t+5}$ represents the survival from birth to age $0-4$ for the $k$ th generation during the period $t$ to $t+5$ and the total births in the $k$ th generation are calculated as:

$$
B_{k}^{t, t+5}=2.5 \sum_{x=15}^{45} P_{x, k-1}^{t}\left(F_{x, k-1}^{t}+S_{x, k-1}^{t, t+5} F_{x, k-1}^{t+5}\right)+B_{I, k}^{t, t+5}
$$

where $B_{I, k}^{t, t+5}$ represents the births to net immigrants during the period.

Starting with the reconstructed 1851 population described above, population data by five-year age groups, sex, and immigrant generation were fitted for every five years from 1851 to 2011, using the fertility, mortality, and international estimates described above. Generational age-sex distributions were fitted to available data: (a) age-sex tabulations for the 1851 and 1861 censuses; (b) population totals for the Canadian-born and foreign-born for the 1871 to 1911 censuses; and (c) age and sex of the Canadian-born and foreign-born for censuses since 1921. In addition, age and sex data are available on the Canadian-born of foreign-born parents (the second generation) for 1921, 1931, 1971, 2001, 2006, and 2011 censuses; subtracting information on the first and second generation from the total Canadian-born population yields estimates for the third-plus generation.

The result of the fitting process is a detailed set of fertility, mortality, and immigration and emigration estimates for 5-year periods from 1851 to 2011, for immigrant generations by age and sex. Because the focus of this paper is on international migration, we present only the immigration and emigration estimates in Appendix Table 2, which also shows emigration estimates by nativity. 
Table A2. International migration estimates for Canada, in 1000s, 1851 to 2011

\begin{tabular}{|c|c|c|c|c|c|}
\hline \multirow[b]{2}{*}{$\begin{array}{l}5 \text {-year period } \\
\text { beginning in }\end{array}$} & \multicolumn{3}{|c|}{ Total population } & \multicolumn{2}{|c|}{ Emigrants } \\
\hline & $\begin{array}{l}\text { Immi- } \\
\text { grants }\end{array}$ & $\begin{array}{l}\text { Emi- } \\
\text { grants }\end{array}$ & $\begin{array}{l}\text { Net immi- } \\
\text { grants }\end{array}$ & $\begin{array}{l}\text { Foreign- } \\
\text { born }\end{array}$ & $\begin{array}{c}\text { Canadian- } \\
\text { born }\end{array}$ \\
\hline 1851 & 216 & 43 & 173 & 9 & 34 \\
\hline 1856 & 136 & 127 & 9 & 23 & 105 \\
\hline 1861 & 140 & 189 & -49 & 32 & 157 \\
\hline 1866 & 120 & 221 & -101 & 35 & 185 \\
\hline 1871 & 233 & 178 & 55 & 25 & 153 \\
\hline 1876 & 117 & 226 & -109 & 29 & 197 \\
\hline 1881 & 397 & 399 & -2 & 48 & 352 \\
\hline 1886 & 283 & 427 & -144 & 47 & 380 \\
\hline 1891 & 116 & 201 & -85 & 16 & 185 \\
\hline 1896 & 134 & 179 & -45 & 13 & 167 \\
\hline 1901 & 524 & 247 & 278 & 12 & 234 \\
\hline 1906 & 1,026 & 493 & 532 & 39 & 454 \\
\hline 1911 & 1,058 & 829 & 229 & 124 & 705 \\
\hline 1916 & 342 & 260 & 82 & 52 & 208 \\
\hline 1921 & 488 & 395 & 93 & 99 & 296 \\
\hline 1926 & 712 & 575 & 137 & 173 & 403 \\
\hline 1931 & 81 & 132 & -50 & 54 & 78 \\
\hline 1936 & 68 & 109 & -42 & 46 & 63 \\
\hline 1941 & 61 & 42 & 19 & 18 & 24 \\
\hline 1946 & 487 & 337 & 150 & 168 & 168 \\
\hline 1951 & 783 & 185 & 598 & 98 & 87 \\
\hline 1956 & 760 & 278 & 482 & 133 & 145 \\
\hline 1961 & 539 & 280 & 259 & 129 & 151 \\
\hline 1966 & 890 & 427 & 463 & 201 & 226 \\
\hline 1971 & 1,053 & 358 & 695 & 175 & 183 \\
\hline 1976 & 771 & 278 & 493 & 139 & 139 \\
\hline 1981 & 678 & 278 & 400 & 145 & 133 \\
\hline 1986 & 1,164 & 213 & 951 & 115 & 98 \\
\hline 1991 & 1,118 & 338 & 780 & 227 & 111 \\
\hline 1996 & 1,217 & 376 & 841 & 221 & 155 \\
\hline 2001 & 1,194 & 203 & 991 & 131 & 72 \\
\hline 2006 & 1,263 & 259 & 1,004 & 173 & 86 \\
\hline
\end{tabular}

